\title{
Introducing the Defense of Independent Invention to Motions for Preliminary Injunctions in Patent Infringement Lawsuits
}

\author{
Michelle Armond $\dagger$
}

\section{INTRODUCTION}

In I954, Jerome Lemelson filed a 150-page patent application describing a video camera positioned to view a production line, with the video picture signal used for automatic quality control. ${ }^{1}$ This and similar applications languished as unpublished "submarine" applications in the U.S. Patent \& Trademark Office ("PTO") for decades, ${ }^{2}$ as Lemelson filed subsequent derivative "continuation" applications, which eventually issued as a disputed series of patents between 1978 and $1994 .^{3}$ In the late 1980s, Lemelson hired attorney Gerald Hosier, who realized the untapped potential of Lemelson's "machine vision" patents. Beginning in September 1989, Hosier amended Lemelson's pending applications to include claims

Copyright (C) 2003 California Law Review, Inc. California Law Review, Inc. (CLR) is a California nonprofit corporation. CLR and the authors are solely responsible for the content of their publications.

$\dagger \quad$ J.D. Candidate, School of Law, University of California, Berkeley (Boalt Hall), 2003; B.S., California Institute of Technology (Electrical Engineering and History). Special thanks to Professor Mark Lemley, Steven Carlson, and the members of the California Law Review, particularly Heather Weaver and Chris Hazuka, for their helpful suggestions. The opinions expressed in this Comment are solely those of the author. 1 dedicate this Comment to my mother Sharyn, my sisters Melody and Jillayne, and to Alex.

1. Nicholas Varchaver, The Patent King, Forbes, May 14, 2001, at 202. Lemelson's critics allege that Lemelson never built his machine vision system, that it would have been inoperable if he had built it, and that Lemelson's original patents describe processes that are distinctly different than how machine vision is or has ever been practiced. $l d$.

2. Lemelson became famous for bis practices of "submarine patenting." See David Rubenstein, Patent Law Overhaul Appeals to GCs, CoRP. Legal Times, July 1998, at 27 (describing "the late Jerome $H$. Lemelson, who was, depending on your viewpoint, either a brilliant and prolific inventor or a sophisticated corporate extortionist and master of the submarine patent").

3. Edward T. Colbert \& Kenneth R. Corsello, Prosecution Latches, NAT'L L.J., Feb. 25, 2002, at A19. See also id. ("Lemelson kept the content of these applications pending for as much as 40 years by filing continuation and divisional applications, which are applications based on and containing the same disclosure as the original application and are entitled to the filing date of the original, parent application."); 35 U.S.C. $\S \S 120-121$ (2000). 
covering bar-code technology. ${ }^{4}$ In November 1989, Hosier scnt demand letters to every company in the electronics, semiconductor, and automobile industry internationally, alleging that they were infringing Lemelson's patents. ${ }^{5}$ Although the companies disagreed, Hosier persisted in his claims, focusing especially on the Japanese companies, betting on their reluctance to battle the U.S. legal system. ${ }^{6}$ By late 1992 , the entire Japanese automobile industry capitulated and agreed to collectively pay Lemelson one hundred million dollars. ${ }^{7}$ Within months, thirty other European and Japanese companies had paid an additional 350 million dollars. ${ }^{8}$

Because of the pervasive use of bar-code technology, Hosier had no shortage of potential licensees; it seemed that almost any company was a potential target. In the mid-1990s Hosier set his sights on the U.S. automobile industry, which initially responded by litigating but eventually settled. ${ }^{9}$ In July 1998, Lemelson sued twenty-six semiconductor companies for infringing its machine vision patents; most settled..$^{10}$ As of 2002, hundreds of companies have paid over one billion dollars to license only Lemelson's bar-code patents. ${ }^{11}$

Those companies that did not settle were threatened with lawsuits. In April 2000, the Lemelson Foundation made good on its threats, suing 438 companies for allegedly using bar-code technology infringing its fourteen patents covering "machine vision" technology. 12 In December 2001, the Lemelson Foundation had ten pending cascs against more than four hundred defendants. It also filed additional lawsuits against companies in the medical, pharmaceutical, paper, and wine making business. ${ }^{13}$

4. Varchaver, supra note 1. As Hosier wrote to one Japanese company in December 1991 during licensing negotiations, "the claims of the pending applications are all being earefully drawn to cover practices in widespread commercial use." Id.

5. Id.

6. Id.

7. Id.

8. Id.

9. Id. (describing Lemelson's legal battles with the U.S. automobile industry where the trial court initially found Lemelson's patents unenforceable and then reversed itself, the Fcderal Circuit denied Ford's interlocutory appeal, and ultimately Ford, GM, and Chrysler settled separately in 1998). See also Ford Motor Co. v. Lemelson, 124 F.3d 227 (Fed Cir. 1997) (unpublished) (denying Ford's interlocutory appeal that prosecution latches should bar enforcement of Lemelson's patents).

10. Brenda Sandburg, Lemelson Foundation Sues 87 in Complaint, RECORDER (San Francisco), Mar. 9, 1999, at 3.

11. Brenda Sandburg, Delay May Block Suits, NAT'L L.J., Feb. 4, 2002, at A21.

12. Brenda Sandburg, Late Inventor's Foundation Sues, Recorder (San Francisco), Apr. 20, 2000 , at 9. The five lawsuits, organized by industry, covered a varied collection including manufacturers using imaging techniques, food producers, durable goods, and manufacturers and retailers of electronics and semiconduetor products. Id. Hosier admitted that the defendants were organized alphabetically. See Victoria Slind-Flor, So Many Cases, You'd Need a Mnemonic Too, NAT'L L.J., May 1, 2000, at B7 (“"These [cases] break nicely into the A suit, the B suit and so on,' Mr. Hosier said. 'This is truly the logic that went behind who went first' on the defendant list.").

13. See Michael Ravnitzky, More Lemelson Suits, NAT'L L.J., Dcc. 17, 2001, at B9. 
Companies that arguably are engaged in, innovative practices have been impacted by Lemelson's practices. For example, Robert Shillman, cofounder of Cognex, a 250 million-dollar company that manufactures machine vision equipment and had not been a target of the Lemelson licensing effort, sued the Lemelson Foundation to invalidate its machine vision patent claims. ${ }^{14}$ Shillman was outraged that his customers frequently sought reimbursement for Lemelson licensing fees that they paid for using Cognex products that were developed independently from Lemelson's ideas. ${ }^{15}$ "It's a tax on every consumer in America.... What was produced by this man that is worth a billion dollars?"16

In light of its profitable practices, the Lemelson Foundation is a leading patent licensing firm ("PLF"). ${ }^{17}$ It reportedly owns five hundred patents, 180 of which are still pending. ${ }^{18}$ According to Hosier, 9I 2 companies collectively have paid 1.2 billion dollars to settle Lemelson lawsuits as of December $2001 .{ }^{19}$ Since 1998 , Hosier has averaged a settlement rate of one company per business day for the Lemelson lawsuits. ${ }^{20}$ Lemelson Foundation demand letters are so pervasive that at least one law firm has begun offering advice on its web site about what to do upon receipt of such a letter. ${ }^{21}$ Other web sites maintain information and updates about pending Lemelson Foundation litigation. ${ }^{22}$ Although the volume of Lemelson litigation is staggering and cases frequently involve hundreds of defendants, ${ }^{23}$

14. Varchaver, supra note 1.

15. Id.

16. Id.

17. Other examples of "PLFs" are TechSearch, LLC, PhoneTel Communications, Inc., and IMS Technology, Inc. See Brenda Sandburg, Trolling for Dollars, ReCorder (San Francisco), July 30, $200 \mathrm{I}$, at 1 .

18. Ravnitzky, supra notc 13. See Symbol Techs., Inc. v. Lemelson Medical, 277 F.3d 1361, 1363 (Fed. Cir. 2002) ("Lemelson Mcdical, Education \& Research Foundation . . . claims to be the assignee of some 185 unexpired patents and many pending patent applications of Jcrome $\mathrm{H}$. Lemelson.”).

19. Ravnitzky, supra note I3. See also Varchaver, supra note I (stating that 750 firms have paid for Lemelson patents at a collective cost of "nearly \$1.5 billion"). This overwhelming success has prompted at least one dispute over the Lemelson contingency fees. See Sufrin v. Hosier, 128 F.3d 594. 596 (7th Cir. 1997). The court stated:

Before [Hosier's previous firm, Hosier \& Sufrin] broke up, it had been retained by .. . Lcmelson ... to prosecute, on a contingent-fee basis, claims of patent infringement against a number of major companies. When the firm broke up Hosier took Lemelson's busincss with him. The claims proved to be immensely lucrative, although the lucre did not begin to flow until years after Hosier \& Sufrin, Ltd. had dissolved. Sufrin's ... claim against Hosier . . . is to roughly a third of the contingent fees generated by the Lemelson retention. So huge are those fees that if Sufrin prevailed Hosier would owe him more than $\$ 70$ million.

$I d$. Ultimately, Sufrin did not prevail on his claim for a portion of the Lemelson contingency fees. $I d$. at $60 \mathrm{I}-02$

20. Ravnitzky, supra notc 13.

21. Lloyd Johnson \& Anastasia D. Kelly, A Unified Front Stops a Legal Juggernaut, CoRP. LEgAL TIMES, Mar. 2002, at 12.

22. Id.

23. See supra notes 10-13 and accompanying text. 
the Foundation has little enthusiasm to go to trial. Rather, it uses such litigation as part of its strategy for obtaining settlements. ${ }^{24}$ As measured by the success of the Lemelson Foundation in obtaining licensing fees, then, it appears the PLF strategy thus far has been immensely effective.

But the Lemelson Foundation is not the only problematic PLF. Lemelson may even find his status as the most aggressive patent enforeer in jeopardy. Now that the delay tactics of submarine patents are unavailable, ${ }^{25}$ inventors are turning to new strategies. For example, Ronald Katz uses the complex nature of otherwise narrowly-defined patents to obtain settlements. Specifically, Katz is known for obtaining lengthy patents whose thousands of claims run into the hundreds of pages. ${ }^{26}$ Companies simply license these patents, effectively "paying [Katz's company] to leave them alone," rather than pay for expensive legal analysis of the patents' seope to determine if they indeed infringe. ${ }^{27}$ This method has yielded hundreds of millions of dollars from some of America's largest corporations, and Katz hopes to make two billion dollars by the expiration of his patents in $2009 .^{28}$

In reeent years, preliminary injunction ("PI") has played an increasingly prominent role in this enforcement trend. Wielded by PLFs and larger companies as the ultimate weapon, a PI inspires fear among alleged infringers and encourages settlement. ${ }^{29}$ For many defendants, a PI "create[s] the financial equivalent of nuclear winter." ${ }^{30}$ As the general counsel of a large company recently explained: "I am so afraid of [a PI issuing], I'm almost forced to the settlement table." ${ }^{.31}$

There are several reasons why this trend in litigation strategy remains successful and why companies faced with patent infringement claims settle rather than litigate. First, patent litigation is expensive, often generating two million dollars in legal fees per patent. ${ }^{32}$ Second, the issuance of a PI against an alleged infringer can result in significant economic hardship, or even drive a company out of business. Third, a PI can deliver a "knock out blow" early in litigation that forces the competitor to the settlement table in

24. See Slind-Flor, supra note 12 ("The most recent suits have been filed but not yet served, and Mr. Hosier said that he hopes to negotiate licenses with many of the defendants before they are served, thereby saving the companies litigation costs."); $i d$. (including a critical opinion that the Lemelson Foundation uses the fact that the infringement lawsuits have been filed "to demonstrate they are serious about bringing these actions").

25. See infra note 186.

26. Eric W. Pfeiffer, Setting Patent Traps, ForBes, June 24, 2002, at 65.

27. Id.

28. Id.

29. See Julie S. Turner, Comment, The Nonmanufacturing Patent Owner: Toward a Theory of Efficient Infringement, 86 CALIF. L. REV. 179, 205 n. 102 (1998).

30. Sandberg, supra note 17 .

31. Id.

32. Id. 
a position of weakness. ${ }^{33}$ Finally, current legal standards governing the issuance of PIs afford indulgent presumptions to the patent owner in establishing its claims for PI relief. ${ }^{34}$ Thus, companies threatened with litigation, and, more specifically, a PI, may feel pressured to settle the claims because the risk of losing the PI motion is too great.

This situation is problematic for several reasons. First, by exercising this level of coercion over competitors, a patent owner can demand potentially inefficient settlements or licensing fees that otherwise would be unavailable. Second, companies engaging in innovation in industries known for high levels of patent procurement and enforcement, such as the semiconductor industry, are particularly vulnerable to PLFs and licensing demands. Faced with the prospect of having to halt production and sales of key products, they may engage in anticompetitive practices with their closest competitors, such as cross-licensing arrangements, to minimize these risks. ${ }^{35}$ Third, equity considerations dictate closing legal loopholes that foster rent-seeking behavior. ${ }^{36}$ Ideally, patent law remedies should encourage innovation, not deter companies engaged in good-faith research and development ("R \& D") efforts by facilitating extortion on the part of aggressive nonmanufacturing PLFs.

Building on the use and application of the independent invention concept in other areas of intellectual property (such as copyright and trade secret law) and in legal and economic scholarship, I propose that, in order to remedy the problems presented by abuse of PIs in patent litigation, courts should recognize an affirmative defense of independent invention to PI motions. This proposal has the benefit of focusing on the defendant's conduct. It protects companies overtly engaged in good-faith $R \& D$ whose efforts may or may not constitute infringement, while ensuring PI remedies for companies that are victimized by the most egregious forms of patent infringement, such as industrial espionage or intentional copying of

33. See Samuel K. Lu, The Fundamentals of Preliminary Injunctions, Permanent Injunctions, and Temporary Restraining Orders in Patent Cases, 572 PLI/PAT 169, 174 (1999). Lu noted:

Among the considerations that would favor a patent owner seeking a preliminary injunction: (1) the possibility of shutting down the aecused infringer immediately, rather than at the conclusion of a long, drawn out litigation; (2) the possibility of scoring a 'knockout blow' against the accuscd infringer, forcing him to the bargaining table in a position of weakness or convincing him to leave the market altogether.

Id.; see also Matthew D. Powers \& Steven C. Carlson, The Evolution and Impact of the Doctrine of Willful Patent Infringement, 51 SYRACUSE L. REv. 53, 100 (2001) (describing permanent injunctions as a "'hammer' that patent owners rely on to compel alleged infringers to purchase a license").

34. See infra notes 108-11 and accompanying text.

35. See Patently Absurd?, Economist Tech. Q., June 23, 2001, at 40 [hereinafter Patently Absurd?].

36. See, e.g., Robert P. Merges, Rent Control in the Patent District: Observations on the GradyAlexander Thesis, 78 VA. L. REv. 359 (1992); Jennifer F. Reinganum, The Timing of Innovation: Research, Development, and Diffusion, in I HANDBOOK OF 1NDUS. ORG. 850 (Richard Schmalensee \& Robert Willig eds., 1989); cf. Mark F. Grady \& Jay 1. Alexander, Patent Law and Rent Dissipation, 78 VA. L. REv. 305 (1992). 
patented inventions. In addition, legal and economic scholars have begun to acknowledge that introducing uncertainty into patent enforcement and eroding patent exclusivity in patent law could improve economic efficiency and social welfare ${ }^{37}$ My proposal is consistent with such scholarship, serving to postpone injunctive relief until after trial, when patent claim invalidity and infringement will have been established more conclusively, and courts can make more accurate assessments of whether permanent injunctive relief is appropriate. Further, this proposal does not permanently foreclose the patent owner from a remedy for infringement, but merely suspends exclusivity during trial and delays questions of remedies until after trial; the harmed patent owner will still be remedied with damages for past infringement, including during the trial, and protected by a permanent injunction afterwards. In this way, the affirmative defense of independent invention to PI motions will foster innovation and aid parties in reaching more equitable and economically efficient settlement agreements by removing the heavy grant of bargaining power that the threat or issuance of a PI confers.

This Comment proceeds in three Parts. Part I details the recent trend in aggressive patent enforcement by PLFs and larger companies. It chronicles the impact of their practices and considers more carefully the reasons these practices are so disturbing in the context of patent law. Part II examines the legal standards and policies underlying PI relief, both in general and specifically in patent litigation. Part III lays out the contours of the independent invention affirmative defense; it draws on notions of independent invention in the contexts of willful patent infringement, copyright law, and trade secret law, as well as on legal and economic scholarship, to demonstrate the benefits of a limited importation of the independent invention defense into patent law.

1

Assessing the Problem: The Impact of Aggressive Patent ENFORCEMENT

Over the past decade, patent enforcement has grown into a multibillion-dollar industry. ${ }^{38}$ PLFs have carved out an entirely new market in purchasing and enforcing patents. Large companies have followed suit with similar tactics, using their expansive patent portfolios not only to compel the payment of (sometimes undeserved) licensing fees but also to cripple some competitors financially or to make it difficult for smaller companies

38. See infra note 47 and accompanying text. 
or new entrants to compete. ${ }^{39}$ Most recently, universities also have joined the enforcement game. ${ }^{40}$

PLFs typically are small organizations formed specifically to enforce patent rights. ${ }^{41}$ While many PLFs are independent companies that have purchased or licensed a wide ranging portfolio of patents from third parties, ${ }^{42}$ others are special subsidiaries designed to enforce the patent portfolios of individual companies. ${ }^{43}$ A growing bar of contingency-fee

39. See infra note 51. The semiconductor industry is well known for its patent "portfolio wars." See Patently Absurd?, supra note 35. Firms innovating in the heavily-patented semiconductor industry run "financial risks when they develop new products," namely the risk of paying considerable fees to license patents from their competitors' considerable portfolios. Id. To combat this problem, many large firms frequently collaborate by engaging in what may be anticompetitive cross-licensing schemes where they exchange rights to use intellectual property, thus immunizing themselves from licensing fee demands or infringement lawsuits. Id. This creates barriers to entry and plaees smaller firms lacking significant intellectual property portfolios at a significant disadvantage. Id.

40. See infra note 59 and accompanying text.

41. See Sandberg, supra note 17 (criticizing one PLF that did not invent, produce, or sell the patented technology and explaining that the PLF "simply makes money by exploiting broad patents that have never really been enforced. It lives, primarily, to sue").

As defined, PLFs hold legal title or exclusive licenses to the patents they enforce, and thus do not include attorneys or law firms simply in the business of patent licensing, litigation, or other enforcement activities on behalf of their clients. Clearly, attorneys or law firms acquiring interests in the patents they enforce could fall within this definition.

42. See, e.g., Josh Goldberg, Patent-Buying Firm Sues Intel for Defamation Over News Article, CHi. Dally L. Bull., Apr. 21, 1999, at 3 (noting TechSearch's "business practice of buying patents, licensing them and then protecting its intcllectual property rights through enforcement against infringers"); Sandburg, supra note 17 (describing TechSearch's practice of buying patent rights from inventors and splitting the licensing proceeds with them, and also describing Pitney Bowes lnc., which exclusively manufactures postage meters, but has "amassed patents on technology for everything from cellular phones to word processors"). Recently a federal jury awarded a ten million-dollar verdict against Gillette in finding its process of manufacturing razor blades in its key product lines infringed two Lemelson patents held by Syndia. This was a significant victory for Syndia, whose entire business is based on licensing the Lemelson patents. Josh Karp, Syndia Cuts into Gillette's Business with Razor Patent Litigation, CoRP. Legal Times, Nov. 2002, at 62.

It has become much easier to purchase and market patents in recent years. See Thomas Schcffey, Branford Businessman's Fortune Is Neato: Digital Data Entrepreneur Simply Filled a Pressing Need, ConN. L. TrlB., Mar. 19, 2001, at S16 (describing a website where patents could be searched and "instantly" purchased over the lnternet).

43. See, e.g., Dainippon Screen Mfg. Co. v. CFMT, Inc., 142 F.3d 1266, 1267-68 (Fed. Cir. 1998). The eourt found that

CFM assigned all of its patents to CFMT, and CFMT granted back to CFM exclusive licenses to those patents in rcturn for a ten percent royalty based on CFM's net sales. CFMT is not an operating company and at all relevant times has been a wholly-owned subsidiary of CFM. Under the above arrangement, CFMT acquired title to [the patent] and granted CFM an exclusive license thereunder. The license agreement provides that CFMT alone is authorized to sublicense the ... patent and to "take appropriate legal action" with respect to infringement.

Id.; IMS Tech., Inc. v. Haas Automation, Inc., 206 F.3d 1422, 1425 (Fed. Cir. 2000) ("IMS is the assignee of the ' 754 patent, which was originally assigned to Hurco Companies... . IMS is a wholly owned subsidiary of Hurco, formcd to license the '754 patent."). 
patent attorneys frequently represents PLFs. ${ }^{44}$ These firms and their attorneys file claims against various corporations, alleging that the companies have infringed or continue to infringe a patent owned by the PLF. Reluctant to face the hassle, expense, and risks of litigation including the issuance of a PI, the corporations often pay licensing fees to the PLFs to dispose of the infringement claims. ${ }^{45}$

Because so many PLF lawsuits against large corporations settle at the demand letter stage prior to litigation or before trial, it is difficult to assess the economic dimensions of PLF licensing activities accurately. ${ }^{46}$ Rough estimates indicate that the level of licensing revenues is staggering; they may be growing at an exponential rate, increasing from a three billiondollar industry in 1980 to a 110 billion-dollar industry in $1999 .{ }^{47}$

Sparked by the notorious tactics of PLFs like the Lemelson Foundation, a consensus is emerging in the legal community that PLFs are opportunistic ventures that abuse a loophole in the legal system by using the threat of litigation and PI relief to extract licensing fees for dubiously

44. See Sandberg, supra note 17 ("The key to the [patent enforcement] industry's success has been a small, yet aggressive, army of lawyers who help enforcers hammer companies with infringement claims.").

Contingency-fee arrangements in patent infringement cases work in a fashion similar to the contingency-fee arrangements in traditional litigation: the attorneys work for small companies and individuals who allege that their patents have been infringed. See David Rubenstein, Contingency Patent Lawyer Fills Unique Niche: To Some He's a Hero, to Others He's No Better than an Extortionist, CoRP. Legal. Times, Mar. 1994, at 3. Clients typically cover expenses and the law firm takes a varying percentage of the outcome, usually around $40 \%$. ld. See also Sandberg, supra note 17 ("Lawyers in the [patent enforcement] field routinely charge contingency fees as high as 45 percent."). However, contingency patent work is diffcrent from other contingency cases, such as personal injury, because clients are not guaranteed to obtain a recovery, and patent litigation matters are significantly morc complex. ld.

A recent case between former partners of such a contingency-fee patent firm, Hosier \& Sufrin, Ltd., provides some insight into the operation of such firms. See Sufrin v. Hosier, 128 F.3d 594 (7th Cir. 1997). At dispute were the contingency fees from the firm's settlements of patent infringement claims on behalf of clients Telesonics Systems, Inc. and the late Jerome Lemelson. Id. at 596. Following the 1986 representation of Telesonics Systems, Inc. on a contingency-fee basis, Hosier "negotiated a lucrative settlement that promised Telesonics tens of millions of dollars of patentlicensing fees." Id. "By the most conservative estimates, the best-known lawyer in the patent enforcement business, Gerald Hosier, has pulled in at least $\$ 400$ million in fees." Sandberg, supra note 17. In 2000, Hosier was listed as the country's top-earning attorney by Forbes magazine. Brenda Sandburg, Inventor's Lawyer Makes a Pile from Patents, ReCorder (San Francisco), July 30, 2001, at 1 [hereinafter Sandburg, Inventor's Lawyer].

For sketches of several prominent contingency-fee patent enforcement attorneys and firms, see generally Sandberg, supra note 17; Sandburg, Inventor's Lawyer, supra (profiling Gerald Hosier).

45. David Brown, A Patent Abuse of the System, Recorder (San Francisco), Aug. 3, 200I, at 6. See supra notes 5-8 and accompanying text.

46. See Sandburg, supra note 17 ("Despitc the big settlements, the [patent enforcement] industry's growth has been largely under the radar. Not even the enforcers themselves know how many companies have been formed in recent years to tap into the lucrative power of the patent.").

47. Id. See also id. ("'In the last three to five years, the business has been growing exponentially because everyone is getting into the act,' said David Braunstein, vice president of the intellectual property consulting firm Fairfield Rcsources International Inc. of Stamford, Conn."). 
valid patents. ${ }^{48}$ Pointing to the magnitude of harm that PLFs cause, larger corporations involved in their own independent research, manufacturing, and selling activities have condemned such tactics through harsh rhetoric ${ }^{49}$ and an increased willingness to band together and litigate PLF claims. ${ }^{50}$ Yet, their condemnation of PLF activities has not stopped these very same corporations from pursuing similar strategies in enforcing their own patent portfolios against other companies. ${ }^{51}$ In the late 1980 s, Texas Instruments was among the first to start suing competitors for infringement of its semiconductor patents. ${ }^{52} \mathrm{IBM}$ alone, which has refined its patent licensing practices to "a fine art," realized 1.7 billion dollars in patent royalties last year. ${ }^{53}$ Similarly, Lucent Technologies obtained four hundred million dollars from its patent portfolio. ${ }^{54}$ Many companies have established licensing departments in recent years and are pursuing "patent factory" approaches to cover future developments in their industry, whereby they simply record inventions on paper while skimping on the underlying experimental work or seek comprehensive protection on the most minor aspects of the innovation. ${ }^{55}$ In some industries, such as the semiconductor industry, the quality and usefulness of filed patents seemingly have decreased. ${ }^{56}$ Companies

48. See, e.g., supra notes $1-15$ and accompanying text.

49. See, e.g., Goldberg, supra note 42 (describing a lawsuit by TechSearch against Intel for defamation and trade disparagement based on statements made in a Wall Street Journal article calling TechSearch a "patent extortionist").

50. See Johnson \& Kelly, supra note 21 (describing efforts of retail manufacturers facing potential patent infringement lawsuits brought by the Lemelson Foundation to band together in joint legal defense committees and litigate the validity of the asserted patent claims); Brenda Sandburg, New Industry Transforms Patent System, ReCorder (San Francisco), July 30, 2001, at 9 ("Cypress is one of a growing number of companies willing to go to court to fight off claims of infringement brought by companies that want money for a patent license.").

51. See Sandburg, supra note 17 ("[T]hough companies that specializc in buying and enforcing patents have earned the unending enmity of corporate executives, that hasn't stopped major corporations from doing exactly the same thing-using claims of patent infringement as an extremely lucrative new way of generating revenue."). Among the first large corporations to begin to license their patents in signifieant numbers were Texas Instruments, AT\&T, IBM, and Fairchild Camera and Instrument Corp. Id.

52. Id. Scholars have recently noted the rise in patenting rates and aggressive enforcement of patent rights in the semiconductor industry. See Pamela Samuelson \& Suzanne Scotchmer, The Law and Economics of Reverse Engineering, 111 YALE L.J. 1575, 1607 (2002). As a result of aggressive semiconductor patenting activity, one economist commented that semiconductor firms encounter a “'thicket' of patents that constrain their inventiveness." Patently Absurd?, supra note 35.

53. More Rembrandts in the Attic, Economist, Jan. 19, 2002, at 53 [hereinafter More Rembrandts].

54. Id.

55. See Sandburg, supra note 17. Similarly, Jerome Lemelson did not build models or perform underlying experimental work to test his technological inventions. Varchaver, supra note 1. Inventing for him was a purely theoretical exercise whereby he perused technical journals to forecast the direction of a particular industry. Id.

56. While semiconductor patent filings doubled per dollar of R \& D spending, employees complained that the average "quality" of their patents declined, as did the number of citations per semiconductor patent in technical literature. Patently absurd?, supra note 35. 
have increasingly consulted intellectual property attorneys and have begun filing patents for purely strategic purposes, either offensively to block competitors' development or defensively to ward off infringement lawsuits. ${ }^{57}$ Some firms are now bringing in outside consultants to assist them evaluating their intellectual property portfolios for patents that may have potential licensing value. ${ }^{58}$ In what may be the latest trend in patent enforcement, major private and public U.S. universities are increasingly suing companies over patent and licensing rights, often seeking royalties into the hundreds of millions of dollars. ${ }^{59}$

In light of these emerging trends of aggressive patent enforcement, especially in particular industries ${ }^{60}$ solutions to effectively close loopholes that foster these practices are of the utmost importance. ${ }^{61}$ One such loophole is the threat of a PI. Because PIs issue early in litigation, on a thin evidentiary record and before a full opportunity at investigating the patent claims' scope and validity, and prompt expensivc settlemcnts, some corporations cede to less-expensive pretrial settlement licensing dcmands which can save both the cost of legal fees during litigation and resulting high settlement costs if an injunction is issued against them.

Providing a new affirmative defense of independent invention would continue to foster innovation by placing some limitations on the patent owner's exclusivity rights during this key initial phase of the patent dispute. In addition, it would provide more certainty to companies that

57. Id.

58. Recently, BT, a British telecom company, recognized the value of a dormant 1989 U.S. patent covcring hyperlinking technology among its fourtcen-thousand-patent portfolio, and brought suit against. Prodigy Communications. More Rembrandts, supra note 53. Interested in finding other overlookcd IP ("Rembrants in the attie"), BT rctained a consulting startup, ipValue, to review its portfolio for othcr potential licensing opportunities in North Amcrica with the hope of realizing one million dollars in licensing revenues within six years. $I d$.

59. Margaret Cronin Fisk, Ivory Towers Fire Back over Patents: More Schools Are Suing Businesses, NAT'L L.J., Aug. 26, 2002, at Al. In recent years, universities have begun to look to their patent portfolios as a method to enhance thcir revenuc streams and recoup their research investments. Id. Two leading examples illustrate this trend. First, in 1999, Genentech reached a two hundred milliondollar settlement over a patent dispute with the University of California over recombinant human growth hormone. $I d$. Second, the University of Rochester is currently involved in arguably the largcst ever U.S. patent case in its lawsuit over the patent rights to Cclcbrex $\circledast$, a drug that has realized three hundred million dollars in sales. $I d$. The Association of University Technology Managers has noted a continuous growth in issued patents and licenses granted by university technology offices following the Bayh-Dole Act of 1986, which pcrmitted univcrsities to own technology based on government-funded research endeavors. $I d$.

60. See supra note 52 .

61. Acadcmic writers have begun to recognize the dimension of this problem and proposc various solutions. See Allen M. Leung, Legal Judo: Strategic Applications of Reexamination Versus an Aggressive Adversary (Part I), 84 J. PAT. \& Trademark OFF. Soc'y 47I, 475 (2002) (proposing patent reexamination as a solution to the scenario of a small company being threatened with patent infringement by an aggressive larger company); Turncr, supra note 29, at 179 (arguing that "injunctive relief for intentionally nonmanufacturing patent owners is antithetical to the goals of the patent system and is economically inefficient as well"'). 
undertake good-faith innovative efforts, instead of solely enforcing intellectual property rights. Thus, firms that want to protect themselves from aggressive patent enforcement could implement effective procedures to document their inventive process and effectively shield themselves from PI relief should a dispute arise. As a result of these measures and additional protections, the firms would be able to continue to innovate. The full contours and ramifications of this proposal will be explored below in Parts III.A and III.B. The next Part will discuss the legal standard for PI relief and highlight the institutional reasons why PI relief has become such an effective litigation tactic.

\section{II}

Patent Infringement Preliminary Injunctive Relief: An EXTRAORDINARY REMEDY

One of the most potent weapons wielded by PLFs and large corporations that aggressively seek to enforce their patents is the threat of a PI. An extraordinary remedy designed to maintain the status quo and preserve the controversy for a meaningful decision after full trial, ${ }^{62}$ a PI bars the defendant from further use, production, or distribution of the allegedly infringing technology. Injunctions can exert extraordinary financial pressure on defendants, and could drive many accused infringers out of business. ${ }^{63}$

Several PI motion and patent litigation realities increase the threatened harm that a PI poses to a defendant. First, PI motions may place parties on unequal procedural and strategic footing. As is common in any complex, fast-moving litigation, the expedited scheduling of PI hearings exerts considerable time pressure on the parties. ${ }^{64}$ The patent ownermovant may be at a significant advantage because the accused infringer will be surprised by the unexpected charges and not have sufficient time to search for relevant prior art or conduct discovery of experts in order to effectively rebut the patent owner's allegations of patent claim validity and

62. Kenneth H. York et al., Cases and Materials on Remedies 223 (5th ed. 1992). See also Canal Auth. of the State of Fla. v. Callaway, 489 F.2d 567, 572 (5th Cir. 1974) ("A preliminary injunction may be issued to protect the plaintiff from irreparable injury and to preserve the district court's power to render a meaningful decision after a trial on the merits."); Dynamic Mfgr., lnc. v. Craze, 46 U.S.P.Q.2d 1548, 1550 (E.D. Va. 1998) ("A preliminary injunetion is designed to preserve the status quo until the Court has an opportunity to fully review the merits of a case at trial.") (internal quotations omitted). In Atlas Powder, the Federal Circuit stated that authorizing the accused infringer to continue in the alleged infringement at the rate it was occurring when the lawsuit was filed "is in no realistic sense maintaining the status quo." Atlas Powder Co. v. Ireco Chems., 773 F.2d 1230, 1231 (Fed. Cir. 1985).

63. See supra note 33 and aceompanying text.

64. See Steven E. Shapiro, Preliminary Injunction Motions in Patent Litigation, 33 1DEA 323, 324 (1993). 
infringement. ${ }^{65}$ Moreover, one empirical study suggests that, in practice, PIs are available primarily to financially stronger plaintiff patent owners. ${ }^{66}$ According to the study, patent lawsuits that included a motion for a PI involved plaintiffs almost twice as large as those plaintiffs in lawsuits where no PI was requested. ${ }^{67}$ This study's findings may indicate that larger companies are more likely to use PIs to exert market dominance and control over their smaller competitors. It also may indicate that although PLFs have attracted much attention due to their notorious tactics, the aggressive enforcement that large corporations engage in may be a more significant problem. ${ }^{68}$ Further, there is some evidence that district courts and the Federal Circuit apply the four-part PI test ${ }^{69}$ unevenly, often affording key presumptions that favor the plaintiff. ${ }^{70}$

Thus, given the magnitude of potential harm that a PI inflicts and the risks of possible issuance, a defendant faced with a credibIe PI motion in a patent infringement lawsuit might choose to settle. Even if a defendant believes it will prevail following a full trial, the defendant may nonetheless settle before trial at a higher licensing rate when a PI is threatened than if only litigation is threatened, because of the fear that a PI may be erroneously issued..$^{71}$ This is a rational choice if the proposed settlement cost is less than the combined costs of defendant's legal fees and the amount it will be undercompensated during trial while its business operations are disrupted by an improperly issued PI. ${ }^{72}$

\section{A. Preliminary Injunctions Generally}

PIs are granted at the discretion of the district court, which balances the maintenance of the status quo with the desire to protect the defendant

65. John G. Mills \& Louis S. Zarfas, The Developing Standard for Irreparable Harm in Preliminary Injunctions to Prevent Patent Infringement, 81 J. Pat. \& Trademark OfF. Soc'y 51, 57 (1999).

66. Jean O. Lanjouw \& Josh Lerner, Tilting the Table? The Use of Preliminary Injunctions, 44 J.L. \& ECON. 573, 575 (2001).

67. Id. at 575 . Further, in such cases, plaintiffs were likely to be significantly economically stronger than the accused infringer. Id. at 575-76. These findings do not necessarily indicate that PLFs, which generally are small enterprises, are not a large concern in patent infringement lawsuit Pls. Many PLFs may be successful at securing their desired settlements after sending threatening letters but before filing suit. See, e.g., supra notes 5-8 and accompanying text. Further, Lanjouw and Lerner's empirical study examined only a small collection of firms (those for which corporate data was available), thus favoring larger companies' with published data rather than smallcr licensing shops. See Lanjouw \& Lerner, supra note 66, at 591 (recognizing that "[o]btaining financial information on small privately held firms is often difficult, so for these firms we have only the measures of size").

68. See supra notes $51-58$ and accompanying text.

69. See infra Part 11.B.

70. By clearly establishing that its patent claims are valid and infringed, a patent owner can obtain $\mathrm{Pl}$ relief, even in the absence of evidence that it is suffering competitive or financial harm. See infra notes 109-11 and accompanying text.

71. See Lanjouw \& Lerner, supra note 66 , at 582-83.

72. Id. 
from the "severity and harshness of an order granted after less than a full hearing." ${ }^{.73}$ When issuing PIs, trial courts traditionally have considered four elements: (1) the substantial likelihood that the plaintiff will prevail on the merits; (2) the substantial threat that the plaintiff will suffer irreparable injury if the PI is not granted; (3) whether the threatened injury to the plaintiff outweighs the threatened harm that the PI may cause the defendant; and (4) whether granting the PI will disserve the public interest. ${ }^{74}$ The trial court's judgment on motions for PIs is reviewed on appeal under the deferential abuse of discretion standard. ${ }^{75}$ Despite similarity in the factors used, the various federal circuit courts have provided varied guidance about how these factors should be applied. ${ }^{76}$ The Supreme Court, meanwhile, has not commented directly on how the merits of a PI motion should be judged..$^{77}$

\section{B. Preliminary Injunctions in Patent Infringement Lawsuits}

PIs were first made available in patent infringement lawsuits by the Patent Act of $1819 .^{78}$ Express statutory authorization in 35 U.S.C. $\S 283$ provides that district courts "may grant injunctions in accordance with the principles of equity to prevent the violation of any right secured by patent, on such terms as the court deems reasonable." 79 Although the statutory framework for evaluating motions for PIs in patent cases has remained relatively stable, the courts' willingness to grant them has varied over time. For example, prior to the establishment of the Federal Circuit in 1982, regional circuit courts required a "beyond question" likelihood of success on the merits to support the issuance of PIs in patent cases ${ }^{80}$ But, since its

73. YORK ET AL., supra note 62, at 223.

74. L.A. Mem'l Coliseum Comm'n v. Nat'l Football League, 634 F.2d 1197, 1200 (9th Cir. 1980); Canal Auth, of the State of Fla. v. Callaway, 489 F.2d 567, 572-73 (5th Cir. 1974).

75. L.A. Mem'l Coliseum, 634 F.2d at 1200; Canal Auth., 489 F.2d at 572.

76. See, e.g., L.A. Mem'l Coliseum, 634 F.2d at 1201 ("In [the Ninth C]ircuit, the moving party may meet its burden by demonstrating either (1) a combination of probable success on the merits and the possibility of irreparable injury or (2) that serious questions are raised and the balance of hardships tips sharply in its favor."); Caulfield v. Bd. of Ed. of City of New York, 583 F.2d 605, 6I0 (2d Cir. 1978). The Second Circuit

has recently clarified the standard for issuance of a preliminary injunetion: there must be a showing of possible irreparable injury and either (1) probable success on the merits or (2) suffieiently serious questions going to the merits to make them a fair ground for litigation and a balance of hardships tipping decidedly toward the party requesting the Id.

preliminary relief.

77. M.A. Cunningham, Preliminary Injunctive Relief in Patent Litigation, 35 IDEA 213, 216 (1995).

78. See id. at 217.

79. 35 U.S.C. $\S 283(2000)$.

- 80. The regional circuit courts generally required plaintiffs seeking a PI to demonstrate a "beyond question" showing of likelihood of success on the merits; that is, to show that their patent claims previously were adjudged valid, that there was a long period of public acquiescence, or that there was conclusive direct technical evidence proving validity. See Shapiro, supra note 64, at 324. See, 
establishment in 1982, the Federal Circuit has developed a specialized body of law on the subject, holding that the legal standard for issuing PIs in patent cases is subject to the law of the Federal Circuit, not that of the regional cireuit in which the action is brought. ${ }^{81}$ As the U.S. Supreme Court has never considered in a plenary fashion the standards for issuing a $\mathrm{Pl}$, the Federal Circuit's rulings on the matter remain controlling law. ${ }^{82}$

In Smith International Inc. v. Hughes Tool Co., ${ }^{83}$ the court's first decision considering PIs in the patent context, the Federal Circuit adopted a balancing test to assess the four factors generally considered by an appellate court in reviewing rulings on PI motions. ${ }^{84}$ According to the court, the factors to be weighed include: (1) whether the movant has established a reasonable likelihood of success on the merits; (2) the potential for irreparable injury if the PI relief is denied; (3) whether hardships suffered by the movant outweigh the potential hardships of the other party; and (4) whether the public interest is favored by issuing the injunction. ${ }^{85}$ In application, the Smith International factors were balanced against one another. However, in its subsequent decision in Reebok International Ltd. v. J. Baker, Inc., the Federal Circuit held that both the likelihood of success on the merits and irreparable harm elements were indispensable for PI relief and the absence of either factor required denial of the PI. ${ }^{86}$

e.g., Simson Bros., Inc. v. Blanchard \& Co., 22 F.2d 498, 499 (2d Cir. 1927) ("We have often said that an injunction pendente lite in a patent suit should not go except when the patent is beyond question valid and infringed."). This hcightened standard stemmed from a general judicial skcpticism of patent rights and the ex parte examination process in the PTO. See Rosenberg v. Groov-Pin Corp., 8I F.2d 46, 47-48 (2d Cir. 1936). Courts afforded little weight to the statutory presumption of patent claim validity and used the irreparable injury requirement to limit the availability of PIs. In addition, courts often denied PI motions where accused infringers were able to pay potential damage judgments, holding that the plaintiff's alleged injury was not irreparable. Mills \& Zarfas, supra note 65 , at 56 . This strict standard resulted in the issuance of few PIs in patent infringement suits and may have contributed to the establishment of the Federal Circuit. See Cunningham, supra note 77, at 217, 219-20.

81. Hybritech Inc. v. Abbott Labs., 849 F.2d 1446, 1451 n.12 (Fed. Cir. 1988). The Federal Circuit opined:

Because the issuance of an injunction pursuant to [35 U.S.C. § 283] enjoins "the violation of any right sccured by a patent, on such terms as the court deems reasonable," a preliminary injunction of this type, although a procedural matter, involves substantive matters unique to patent law and, therefore, is governed by the law of this court. We recognize, however, that purely procedural questions involving the grant of a preliminary injunction are controlled by the law of the appropriate regional circuit.

ld.

82. Donald S. Chisum, Chisum on Patents $§ 20.04[1]$ [a][ii] (2002). The Supreme Court has affirmed orders granting PIs as not involving an abuse of discrction by the lower courts in two cases. Id.

83. 718 F.2d I573 (Fed. Cir. 1983).

84. See Cunningham, supra note 77 , at 220.

85. See H.H. Robertson Co. v. United Steel Deck, Inc., 820 F.2d 384, 387 (Fed. Cir. 1987); Smith Int' 1,718 F.2d at $1578-79$.

86. 32 F.3d 1552, 1556 (Fed. Cir. 1994) (" $[A]$ movant cannot be granted a preliminary injunction without findings by the district court that the movant carried its burden on both factors [likelihood of success on the merits and irreparable harm]."). See also Amazon.com v. Barnesandnoble.com, 239 F.3d 1343, 1350 (Fed. Cir. 2001) ("Our case law and logic both require that a movant cannot be granted a 
In assessing the presence of each of these four factors, the Federal Circuit initially adopted a more lenient approach than past courts, effectively expanding the availability of PIs to patent owners. ${ }^{87}$ The court justified this expansion on two primary policy grounds. First, the Federal Circuit viewed patents as property rights, which it correspondingly has embodied with the attributes of real property, including the right to exclude others. ${ }^{88}$ The court also speculated that a refusal to issue injunctions in favor of the imposition of monetary damages on infringers would lead to unconstrained infringement, ${ }^{89}$ effectively turning patents into a compulsory license. ${ }^{90}$ Further, if PIs were not available, patents would retain only a fraction of their intended value and innovators would no longer have "as great an incentive to engage in the toils of scientific and technological research." ${ }^{.91}$

preliminary injunction unless it establishes both of the first two factors, i.e., likelihood of success on the merits and irreparable harm.").

87. Within the first two years of its incipiency, the Federal Circuit eased the showing necessary to secure Pl relief in patent cases. It relaxed the showing required for the first factor, a likelihood of success on the merits, and permitted a presumption of irreparable injury on a clear showing of the first factor See lan Ayres \& Paul Klemperer, Limiting Patentees' 'Market Power Without Reducing Innovation Incentives: The Perverse Benefits of Uncertainty and Non-Injunctive Remedies, $97 \mathrm{MICH}$. L. Rev. 985, 1020 (1999). Empirical evidence suggests that, from the Federal Circuit's establishment in 1982 until the early 1990s, Pls became more prevalent than under the. prior regional circuit court regime. M.A. Cunningham's 1993 study found that the Federal Circuit affirmed district court grants of Pls $58 \%$ of the time, whereas circuit courts, prior to the Federal Circuit's establishment, affirmed district court grants of PIs only $41 \%$ of the time. See Cunningham, supra note 77, at 230-33. Similarly, after the Federal Circuit eased the Pl standard, district courts granted Pl motions in patent infringement lawsuits $61 \%$ of the time, compared to only $41 \%$ of the time prior to establishment of the Federal Circuit. $I d$. at 230-3l. In the early 1990s, this trend sparked concern among practitioners that Pls in patent infringement lawsuits would become too prolific and ruin American businesses. See, e.g., Edmund L. Andrews, Patents: Rise Feared in Foreign Injunctions, N.Y. Times, Oct. 13, 1990, at A34 (" $[S]$ ome lawyers think the battle [between Motorola and Hitachi] foreshadows a day when foreign companies use their patents to shut down American companies with court injunctions."). A patent dispute between Motorola and Hitachi typified this fear when a federal district judge ruled that each company had violated the other company's patent and issued an injunction ordering both companies to halt production. Id. See also Motorola, Inc. v. Hitachi, Ltd., 750 F. Supp. 1319, 1338 (W.D. Tex. 1990). On appeal, the injunctions were overturned. Motorola, Inc. v. Hitachi, Ltd., 923 F.2d 868 (Fed. Cir. 1990).

88. See H.H. Robertson, 820 F.2d at 390 ("The nature of the patent grant thus weighs against holding that monetary damages will always suffice to make the patent owner whole, for the principal value of a patent is its statutory right to exclude."); Smith Int ' l, 718 F.2d at 1577 (arguing that under the patent statute, "patents shall have the attributes of personal property [including] the right to exelude others").

89. See H.H. Robertson, 820 F.2d at 390 ("The opportunity to practice an invention during the notoriously lengthy course of patent litigation may itself tempt infringers.").

90. This argument fails with respect to Pls because permanent injunctions are routinely issued after trial and infringement would only be permitted during court proceedings. See CHISUM, supra note 82 , at $\S 20.04[2]$ ("A patent owner prevailing on the merits of a patent infringement claim will usually be granted a permanent injunction against future infringement unless the public interest otherwise dictates.").

91. Smith Int'l, 718 F.2d at 1578. 
The following Subsections highlight the evolution in the Federal Circuit's thinking regarding each element of the four-factor PI standard. The Federal Circuit has revisited and reevaluated these standards repeatedly, creating guidelines and exceptions to these rules that suggest that PIs are more difficult to obtain than a superficial reading may suggest. The contours of this development, especially with regard to the first two factors, which are most relevant to the PLF phenomenon, are explored in the next several Subsections.

\section{Likelihood of Success}

In Atlas Powder Co. v. Ireco Chemicals, the Federal Circuit officially rejected the "beyond question" standard for demonstrating likelihood of success in favor of a less stringent "clear showing" standard. ${ }^{92}$ The court held that "[t]he burden upon the movant should be no different in a patent case than for other kinds of intellectual property, where, generally, only a 'clear showing' is required." success, then, movants must make a "clear showing" that they have title to the patent at issue, ${ }^{94}$ that the patent is valid, ${ }^{95}$ and that the patent has been infringed. ${ }^{96}$ Traditionally, movants proved patent validity through evidence of prior adjudication, ${ }^{97}$ a long period of industry acquiescence, ${ }^{98}$ or by effectively refuting a defendant's invalidity challenges. ${ }^{99}$ Infringement is

92. 773 F.3d 1230 (Fed. Cir. 1985). See also Mills \& Zarfas, supra note 65, at 56 (discussing Atlas Powder).

93. Atlas Powder v. Ireco Chems., 773 F.2d 1230, 1233 (Fed. Cir. 1985).

94. Establishing clear title to a patent is generally a routine matter, requiring production of a certified copy of the patent or recorded assignment. See Robert C. Dorr \& Bradford J. Duft, Patent Preliminary Injunctive Relief, 60 J. Pat. \& TRademark Off. Soc'y 597, 603 (1978) ("Title in the movant is usually demonstrated by producing a certified copy of the patent. If the movant is an assignee of the patent, a certified copy of the assignment, as recorded in the U.S. Patent and Trademark Office, is necessary.").

95. See Tate Access Floors v. Interface Architectural Res., 279 F.3d 1357, 1367 (Fed. Cir. 2002) (stating in context of likelihood of success analysis that "[0]ur law requires patent challengers to prove invalidity by clear and convincing evidence").

96. See Atlas Powder, 773 F.2d at 1233 ("Thus, when a patent owner 'clearly shows' that his patent is valid and infringed, a court may, after a balance of all of the competing equities, preliminarily enjoin another from violating the rights secured by the patent."). The Federal Circuit rcaffirmed and clarified this "clear showing" standard in Reebok, where it required the movant to establish a reasonable likelihood of suecess on the merits regarding both patent claim validity and infringement. Reebok Int'I Ltd. v. J. Baker, Inc., 32 F.3d 1552, $1555-56$ (Fed. Cir. 1994).

97. See, e.g., Hybritech, Inc. v. Abbott Labs., 849 F.2d 1446, I452 (Fed. Cir. 1988) ("It is wellestablished that in context of a motion for preliminary injunction against further infringement of a patent, the patent holdcr may use a prior adjudication of patent validity involving a diffcrent defendant as evidence supporting its burden of proving likelihood of success on the merits.").

98. See, e.g., Ortho Pharm. Corp. v. Smith, 15 U.S.P.Q.2d 1856, I862 (E.D. Pa. 1990) (noting that fifteen years of "industry-wide acquiescencc" helped to bolster the patent owner's claims of nonobviousness in arguing for a PI).

99. See, e.g., Tate Access Floors, 279 F.3d at 1365 ("In order to demonstrate likely success on the merits, [the plaintiff] must show that, in light of the presumptions and burdens applicable at trial, it 
determined by a three-step process: (1) interpreting the claim language; (2) assessing the nature of the infringer's acts; and (3) applying the claims to those acts. ${ }^{100}$

The Federal Circuit recently clarified the validity and infringement analyses in the PI context. In Amazon.com, Inc. v. Barnesandnoble.com, Inc. ${ }^{101}$ the court struck down a PI issued by the district court, holding that, "whether performed at the preliminary injunction stage or at some later stage in the course of a particular case, infringement and validity analyses must be performed on a claim-by-claim basis," 102 and the claim terms must be interpreted consistently during both analyses. ${ }^{103}$ This new standard for opposition to PI motions may indicate that the Federal Circuit is sending a strong message to district courts that they should be more rigorous and systematic in their evaluation of PI motions, rather than relying on vague notions that the "clear showing" standard has been met.

More importantly, the eourt clarified the parties' burdens in PI hearings. The court discussed its prior jurisprudence that the patent owner, although not required to show validity beyond question, needed to present a clear case of validity. ${ }^{104}$ The eourt clarified the defendant's lesser burden in resisting a PI. In invalidating a patent claim on a motion for summary judgment prior to trial, the defendant must establish invalidity by clear and convincing evidence. ${ }^{105}$ However, the court emphasized that defendants must meet a lesser standard at a PI hearing, only needing to raise a "substantial question as to invalidity" to bar issuance of a PI, noting: "Vulnerability is the issue at the preliminary injunction stage, while validity is the issue at trial." 106 The defendant met this burden by producing prior art that clearly taught key limitations of the claims in the patents at

will likely prove that [the defendant] infringes the asserted claims of the [patent] and that the patent will likely withstand [the defendant's] challenges to its validity.").

100. See, e.g., Am. Home Prods. Corp. v. Johnson \& Johnson Corp., 22 U.S.P.Q.2d 1561, 1566 (E.D. Pa. 1991).

101. 239 F.3d 1343, 1347 (Fed. Cir. 2001). Issuing a PI on Amazon's single-action ordering system patent, whieh had not been litigated previously or reexamined, may have represented the high water mark of PIs in patent infringement lawsuits and surprised many contemporaries. PTO Commissioner Q. Todd Dickinson commented on the injunction:

It's interesting because [Amazon's patent is] one of the first Internet patents to come to at least one conclusory stage of the litigation process. ... A federal judge found that the patent was sufficiently valid to issue a preliminary injunction, which is rather an extraordinary thing, right in the face of the Christmas holiday season. I thought it was kind of amazing, to be honest, and tends to suggest that the patent has validity.

James Gleick, Patently Absurd, N.Y. TimEs MAG., Mar. 12, 2002, at 44.

102. Amazon.com, 239 F.3d at 1351. The court criticized the imprecise validity analysis undertaken by the district court, which eonsidered whether references that the defendant introdueed invalidated the patent generally, rather than considering the invalidity of particular claims. Id. at 1359 .

103. Id. at 1351 .

104. Id. at 1359 .

105. Id. at $\mathrm{I} 358-59$.

I06. Id. at 1359 . 
issue, arguing the missing elements could be filled in by a person of ordinary skill in the art. ${ }^{107}$ In highlighting the patent owner's higher burden for establishing validity and defendant's comparatively lower burden for refuting it, the court suggested that PIs are effectively more difficult to acquire than to defeat, and emphasized that the clear showing of a likelihood of success on the merits required to obtain a PI is a formidable barrier to overcome.

\section{Irreparable Injury}

Generally, irreparable injury denotes cases in which the petitioner cannot obtain full compensation through money damages following a full trial. ${ }^{108}$ Under Smith International, ${ }^{109}$ the court will presume irreparable injury when the petitioner makes a clear showing of a likelihood of success on the merits (that is, a clear showing of patent claim validity and infringement), superficially suggesting that this factor does not add much to the first factor. ${ }^{110}$ In H.H. Robertson Co. v. United Steel Deck, Inc., the Federal Circuit held that this presumption stemmed from "the finite term of the patent grant," which "thus weigh[ed] against holding that monetary damages will always suffice to make the patentee whole, for the principal value of a patent is its statutory right to exclude." 111 Nonetheless, the court later emphasized in Illinois Tool Works, Inc. v. Grip-Pak, Inc. that the presumption of irreparable injury is rebuttable. ${ }^{12}$ For example, the defendant may offer evidence that the plaintiff licensed the patent in the past or delayed in bringing the lawsuit. ${ }^{113}$

Although many district courts routinely cite Smith International and other early Federal Circuit decisions that afforded plaintiffs a rebuttable presumption of irreparable harm, ${ }^{14}$ and the Federal Circuit seemingly has

107. Id. at $1359-60$.

108. H.H. Robertson Co. v. United Steel Deck, Ine., 820 F.2d 384, 390 (Fed. Cir. 1987).

109. Smith Int'l, Inc. v. Hughes Tool Co., 718 F.2d 1573 (Fed. Cir. 1983).

110. Amazon.com, 239 F.3d at.1350. Sce also Smith Int'l, 718 F.2d at 1581 ("We hold that where validity and continuing infringement have been clearly established, as in this ease, immediate irreparable harm is presumed.").

111. 820 F.2d at 390.

112. 906 F.2d 679, 682 (Fed. Cir. 1990).

113. See Polymer Techs. v. Bridwell, 103 F.3d 970, 975 (Fed. Cir. 1996). The court held that [a]bsent a finding clearly negating irreparable harm, such that future infringement is no longer likely, that the patent owner is willing to forego its right to exclude by licensing the patent, or that the patent owner had delayed in bringing suit, there was no basis for finding the presumption of irreparable harm was overcome. Id.

114. For an example of this perfunctory type of presumption-based analysis, see Anton/Bauer, Inc. v. PAG, Ltd, Civil Action No. 3:01 CV 577 (CFD), 2002 U.S. Dist. LEXIS 11583, at*25 (D. Conn. 2002). The eourt stated:

A showing of validity and infringement raises the rebuttable presumption of irreparable harm.... If there is no evidence to refute the presumption of irreparable harm, the presumption stands... Here the Court does not find PAG's evidence to counter the 
reaffirmed this standard repeatedly, a current split in opinion within the Federal Circuit has muddled the irreparable harm analysis. ${ }^{115}$ Despite the Smith International ruling, the Federal Circuit, in other cases, has not applied the rebuttable presumption of irreparable harm, but instead has required persuasive arguments to demonstrate the existence of actual harms. For example, in High Tech Medical Instrumentation, Inc. v. New Image Industries, Inc., the Federal Circuit reversed a district court's grant of a patent owner's PI motion because neither the district court nor the patent owner had identified any specific harm the patent owner would suffer from denial of PI relief, but instead had relied entirely on the rebuttable presumption of irreparable harm. ${ }^{116}$ Similarly in Eli Lilly \& Co. v. American Cyanamid Co., the Federal Circuit upheld a denial of a PI, declining to apply the presumption of irreparable harm automatically. ${ }^{17}$ The court rejected Eli Lilly's contentions that, apart from the presumption, it would suffer lost profits resulting in irreparable harms to its "overall pharmaceutical research efforts." 118 Since an award of money damages would be an adequate remedy after trial and the defendant could satisfy such a judgment, no independent irreparable harm resulted. ${ }^{119}$

presumption of irreparable harm....[T]he Court finds that any solicitation by PAG of infringing sales of the [patented device] will cause irreparable harm to Anton/Bauer.

Id. (citations omitted).

115. See, e.g., Tate Access Floors v. Interface Architeetural Res., 279 F.3d 1357, 1364 (Fed. Cir. 2002) ("[The plaintiff] established with objective evidenee that it would suffer irreparable harm absent a preliminary injunction despite also being entitled to a presumption of irreparable harm due to its strong showing of validity and quite clear showing on infringement.") (internal quotations omitted); Canon Computer Sys., Inc. v. Nu-Kote Int'I, Ine., I34 F.3d 1085, 1090 (Fed. Cir. 1998) ("Furthermore, because the district court did not clearly err in concluding that Canon made a strong showing of a likelihood of success on the merits, Canon is entitled to a presumption of irreparable harm.") (citing Atlas Powder v. Ireco Chems., 773 F.2d 1230, 1232-33 (Fed. Cir. 1985)); Polymer Techs., 103 F.3d at 973 ("If [the plaintiff-patent owner] clearly established the first factor (by making a 'clear showing' of both validity and infringement), it was entitled to a rebuttable presumption in its favor regarding the second factor.") (quoting Smith Int'l, 718 F.2d at 1579). The Federal Circuit explicitly noted this praetice in Purdue Pharm. v. Boehringer Ingelheim GMBH:

Considering the infringement, anticipation, and inequitable eonduct arguments [the patent owner persuasively argued] above, we find no error in the district court's holding that [the patent owner] made a clear showing of its likely success on the merits. Therefore, under the rule prevailing in our circuit, [the patent owner] was entitled to a rebuttable presumption of irreparable harm.

237 F.3d 1359, 1367 (Fed. Cir. 2001).

116. 49 F.3d 1551, 1556 (Fed. Cir. 1995). After rejecting the patent owner's infringement arguments, the court reversed the lower court's injunction order, noting that the patent owner did not suffer irreparable harm when it did not currently license or sell the patented invention in the same market as the infringer and had previously offered a license to the alleged infringer. The court suggested that the patent owner's harm was compensable through monetary relief. Id. at 1556-57.

117. 82 F.3d 1568 (Fed. Cir. 1996).

118. Id. at 1578. It noted that recognizing this as an irreparable harm would enable any manufacturer with an R \& D program to propound a similar argument and "would convert the 'extraordinary' relief of a preliminary injunction into a standard remedy, available whenever the plaintiff has shown a likelihood of success on the merits." Id.

119. Id. at 1578-79. 
Eliminating the presumption of irreparable harm and requiring patent owners to show specific harms that they would suffer may remove the danger of nonmanufacturing PLFs seeking PI relief against companies that incorporate patented technology into their products. ${ }^{120}$ Because nonmanufacturing PLFs likely would suffer only the harm of lost royalties during litigation, and courts have held that monetary damages alone do not constitute irreparable injury meriting PI relief, ${ }^{121}$ PLFs typically would not satisfy this prong and would lack a credible basis for seeking PI relief. Thus, requiring a showing of substantive harm likely would address the problem of nonmanufacturing PLFs obtaining PI relief.

However, even if the Federal Circuit removes the presumption of irreparable harm and requires a showing of actual harm, there is still room for an independent invention defense in patent law. Although PLFs largely may be excluded from PI remedies, the danger would remain that companies that could make semi-credible arguments of harms, such as lost market share, could still use the availability of PIs in much the same manner to extract dubious licensing fees. The policy arguments underlying introducing independent invention-mainly protecting and encouraging good-faith innovative efforts by delaying determinations of validity and infringement against such companies-are still applicable to corporate patent enforcement.

\section{Balance of Hardships}

Courts have placed little emphasis on the "balance of hardships" factor. ${ }^{122}$ District courts are granted considerable discretion in weighing this element and usually will grant PI relief unless the balance tips decidedly in favor of the defendant. ${ }^{123}$ The Federal Circuit has emphasized:

120. See Turner, supra note 29 , at 207 (arguing that nonmanufacturing owners do not suffer "irreparable harm sufficient to justify injunctive relief"). Eliminating the presumption of irreparable harm would revive it as a separate substantive rcquirement under the PI standard. This move would be consistent with other critiques of Pls, specifically Professor Douglas Laycock's argument that the irreparable harm requirement was "dead," since in many cases plaintiffs obtain equitable relief because damages sometimes do not satisfy a court's stringent dcfinition of an adequate remedy. Douglas Laycock, The Death of the Irreparable Injury Rule, 103 HARv. L. Rev. 687, 688, 692 (1990). See also Douglas Laycock, The Death of The IrReparable Injury Rule (1991).

121. See llinois Tool Works, Inc. v. Grip-Pak, Inc., 906 F.2d 679, 683 (Fed. Cir. 1990). The court noted:

Application of a concept that every patentee is always irreparably harmed by an alleged infringer's pretrial sales would equally disserve the patent system. Like all generalities, neither conccpt is universally applicable and, knowing that the court will do so, patentees should consider, weigh, and balance all of the equitable circumstances, in light of the established jurisprudence, before moving for a preliminary injunction.

Id.

122. See Cunningham, supra note 77 , at 227 .

123. See, e.g., Hybritech, Inc. v. Abbott Labs., 849 F.2d 1446, 1457-58 (Fed. Cir. 1988) (noting that the Federal Circuit has "never . . . required, as a prerequisite to awarding preliminary injunctive relief, that the district court expressly find the existenee of this factor. Here, the district court 
The hardship on a preliminarily enjoined manufacturer who must withdraw its product from the market before trial can be devastating. On the other hand, the hardship on a patentee denied an injunction after showing a strong likelihood of success on validity and infringement consists in a frequently and equally serious delay in the exercise of his limited-in-time property right to exclude. Neither hardship can be controlling in all cases. Because the court must balance the hardships, at least in part in light of its estimate of what is likely to happen at trial, it must consider the movant's showing of likelihood of success. Yet, a court must remain free to deny a preliminary injunction, whatever be the showing of likelihood of success, when equity in the light of all the factors so requires. ${ }^{24}$

This factor implicates significant equity concerns and could potentially block the issuance of a PI where a nonmanufacturing patentee is seeking to restrain a manufacturing infringer who unwittingly independently developed a patented technology. However, due to the relative unimportance of this factor in PI jurisprudence generally, and in the PLF context in particular, it will not be considered in more detail.

\section{Public Interest}

The public interest affects the court's decision to grant or deny a PI only on rare occasions, ${ }^{125}$ and it is not as directly relevant to the PLF context. Most courts decide that the policies supporting the patent system outweigh any adverse impact that would be caused by the removal of an allegedly infringing product. ${ }^{126}$ The public interest element weighs in favor of the defendant only if it implicates a critical public health or safety interest, such as medical care or the environment. ${ }^{127}$ For instance, in Hybritech,

considered thc balance of hardships between the parties and concluded that 'neither party has a clear advantage"'). The balance has tipped in favor of the defendant in cases where the defendant is merely using the infringing apparatus and does not compete with the plaintiff, wherc the defendant is a small company with little impact on the plaintiff's overall market, or where the injunction would idle a substantial manufacturing plant. See, e.g., Am. Cyanamid Co. v. U.S. Surgical Corp., 833 F. Supp. 92, 133 (D. Conn. 1992) (noting that the infringer's potential losses from a PI would be larger than the patent owner's potential losses if no Pl issued); Tensar Corp. v. Tenax Corp., 24 U.S.P.Q.2d 1605, 16 I4 (D. Md. 1992) (finding little market impact); Gilbert \& Barker Mfg. Co. v. Bussing, 10 F. Cas. 348,349 (C.C.S.D.N.Y. 1875) (finding that the defendant was not in competition with the plaintiff).

124. Illinois Tool Works, 906 F.2d at 683.

125. See, e.g., Alliance Research Corp. v. Telular Corp., 859 F. Supp. 400, 406 (C.D. Cal. 1994) (noting that the public has an interest "both in protecting patent rights and in ensuring that markets are competitive" but that "the public interest is not a critical factor in this case"); Tensar Corp. v. Tenax Corp., 24 U.S.P.Q.2d 1605, 1614 (D. Md. 1992) (noting that "no significant public interest exists in this litigation between private parties," and that the public interest factor is therefore "neutral").

126. See A.W. Indus. Inc. v. Elec. Connector Serv. Inc., 46 U.S.P.Q.2d 1218, 1224 (S.D. Fla. 1997) ("The public interest is clearly served by protecting rights secured by valid patents.").

127. See Rubbermaid Comm. Prods., Inc. v. Contico Int'l, Inc., 836 F. Supp. I247, I263 (W.D. Va. 1993) ("[B]ecause the product at issue is, after all, one waste receptacle among many and not a wonder drug in short supply, the public will not be harmed significantly by its removal from the 
Inc. $v$. Abbott Laboratories, the public interest factor militated against an injunction because the court reasoned that continued availability of the defendant's cancer and hepatitis test kits furthered public health interests. ${ }^{128}$

The successive clarifications of the PI standard have not eliminated the danger that the availability of PIs can have significant negative effects on patent licensing arrangements. Although district courts apply a fourprong test in evaluating PI motions, the key and only required factors regulating the issuance of PIs are the likelihood of success on the merits and irreparable harm elements. Since a clear showing on a likelihood of success entitles the patent owner to a presumption of irreparable harm, the likelihood of success factor is the true battleground at PI hearings. Thus, the strength of the parties' potential cases on this element will strongly inform their settlement discussions. Although removing the presumption of irreparable harm and requiring patent owners to establish individual harms will make Pls more difficult for PLFs to obtain, since lost profits do not qualify as irreparable harm, this is at best a starting point and will not resolve aggressive patent enforcement by other entities that can show competitive harms that courts may recognize as irreparable. The creation of an independent invention affirmative defense would promote important patent policy goals of innovation and commercialization of new technologies by firms engaged in good-faith innovative efforts. ${ }^{129}$ The scope of this new defense, its policy implications, and analogies to other areas of intellectual property law are explored in the next Part.

III

\section{Independent Invention as a Defense to Preliminary Injunction MOTIONS IN PATENT INFRINGEMENT LAWSUITS}

Several developments suggest that the PI standard in patent lawsuits should be reexamined. First, the recent trend in aggressive enforcement by PLFs and in certain industries, such as the semiconductor industry, suggests that companies engaged in innovation need increased protection against demand letters and patent infringement allegations designed to elicit questionable royalty payments. Second, recent patent disputes over PI

market."); see also Cunningham, supra note 77, at 228-29 ("Either because a product's availability is not threatened by the issuance of an injunction or because its availability does not dircctly affect the health or livelihood of the public, most controversies involving patents will not implicate the public interest ...."). For examples of medical care and environmental cases implicating the public interest, see Ethicon Endo-Surgery v. United States Surgical Corp., 855 F. Supp. 1500, 1517 (1994) (noting that the withdrawal from the market of a popular surgical device that many surgeons had bcen trained to use "could have serious disruptive effect on surgical practice"); Am. Sterilizer Co. v. Surgikos Inc., 17 U.S.P.Q.2d 1081, 1083 (N.D. Tex. 1990) (holding that an injunction would damage the public interest since the public has a vested interest in reducing toxic emissions that the defendant's device produces).

128. 849 F.2d 1446, 1458 (Fed. Cir. 1988).

129. See infra note 177 and accompanying text. 
relief, such as Amazon.com ${ }^{130}$ and High Tech Medical ${ }^{131}$ suggest that the Federal Circuit's continuing redefinition of the PI standard is narrowing the circumstances under which PIs are available. Third, academics have questioned the economic efficiency of PIs and others have argued for the inclusion of a generalized independent invention defense in patent law.

This Part proceeds in four Seetions. Section A considers how an affirmative defense to motions for PIs would work in practice. Such a defense will reduce the negative implications of a PI threat and allow defendants with actual, documentary evidenee that they independently invented an allegedly infringing technology to continue using the technology during the course of the litigation. Section B considers how this defense is supported by overall patent policies to promote and protect innovative efforts in an economically efficient manner. Seetion $\mathrm{C}$ considers independent invention as adopted in other areas of intellectual property law and argues that the defense could similarly be used effectively at the early stages of patent litigation. Section D explores potential issues and difficulties in the implementation of this proposal.

\section{A. The Proposal: Allowing Preliminary Injunction Motions in Patent Infringement Lawsuits to Be Opposed on Grounds of Independent Invention}

For purposes of my proposal, "independent invention" occurs when an entity ${ }^{132}$ endeavors to produce a technological innovation independently, expending the R \& D costs necessary to develop the innovation from the prior state of the technological field. If a company were to copy all or portions of the innovation at issue in the litigation or use it as a research aid or reference, the innovation would not qualify as an independent invention. ${ }^{133}$ Under eurrent patent litigation practices, parties to a lawsuit dispute elements of the four-factor PI test. ${ }^{134}$ A plaintiff-patent owner prepares a motion for a PI, and at a hearing makes a showing under the traditional

130. See supra notes 101-05 and accompanying text.

131. See supra note 116 and accompanying text.

132. "Entity" encompasses an individual, small business, or large corporation. My proposal is likely to be most applicable to corporations.

133. A difficult question is whether good-faith attempts to design around patented technology should be categorized as independent invention under my proposal. The Federal Circuit repeatedly has encouraged efforts to design around patented products. See, e.g., Westvaco Corp. v. Int'l Paper Co., 991 F.2d 735, 745 (Fed. Cir. 1993) ("[D]esigning or inventing around patents to make new inventions is encouraged.... It should not be discouraged by punitive damage awards except in cases where conduct is so obnoxious as clearly to call for them.") (citations and internal quotations omitted). For policy reasons discussed later in this Comment, and because the "design-around" label could be affixed to a broad range of behaviors that would create a difficult line-drawing problem, good-faith attempts to design around patented technology are not encompassed within the definition of "independent invention" for purposes of my proposal. See infra notes 223-27 and aecompanying text.

134. See supra notes 83-86 and accompanying text. 
four-factor test to demonstrate why the court should grant PI relief. ${ }^{135}$ The defendant then responds with its own challenge to patent validity or offers evidence showing that the patent is not infringed. By introducing independent invention as an affirmative defense to such a PI motion, the defendant would have the additional and separate option of presenting evidence that it independently developed the technology at issue. Thus, an accused infringer who could not or did not want to mount a challenge to the plaintiff-patent owner's allegations of validity and infringement could present evidence of independent invention to prevent a PI from issuing. In this context, independent invention is not another factor the court must consider in its PI analysis; rather, independent invention is a complete affirmative defense to a charge of infringement in the PI context much as self-defense is a complete defense to a murder charge in criminal law.

Given that independent invention is an affirmative defense under my proposal, the defendant would logically bear the burdens of pleading and producing clear and convincing evidence that it likely independently invented the disputed innovation. ${ }^{136}$ Once the defendant has met its burden, the plaintiff then would have the option of rebutting the defendant's showing, for example by presenting evidence that the defendant copied its technology or otherwise was aware of plaintiff's patented products.

The parameters of my proposal allow defendants with concrete documentary evidence that they independently invented the allegedly infringing technology to continue using the technology during the course of litigation. ${ }^{137}$ If, at the conclusion of trial, the defendant's technology is deemed an infringement, the defendant would be permanently enjoined from further use and assessed damages for past infringement, including any infringement that occurred during the trial. ${ }^{138}$ If the court ultimately finds that no infringement occurred, then the defendant need not seek damages from the plaintiff for erroneous restraint because the court never issued an

135. This showing includes why the plaintiff's patent claim is valid and infringed by the defendant and, depending on the court, why the defendant's infringement is causing irreparable harm. See supra Parts II.B.1 \& II.B.2.

136. A recent proposal for a nonexclusive patent system also endorsed placing the burden of proof to show independent invention on the defendant accused of infringement. See John S. Liebovitz, Note, Inventing a Nonexclusive Patent System, 111 YALE L.J. 2251, 2275-76 (2002). By contrast, requiring the patent owner to bear the burden of disproving independent invention would effectively require that plaintiffs show deliberate copying or willful infringement at the Pl stage. Because of the practical and evidentiary difficulties and uncertainties that already accompany P1 hearings, this would be exceptionally inadvisable and a near impossible burden for plaintiffs to meet, as direct or circumstantial evidence of willful infringement often reveals itself only after full discovery. See supra notes 64-65 and accompanying text.

137. Such evidence could be in the form of research records, elean room development procedures, written communications, and other records. See also Liebovitz, supra note 136, at 2276 (proposing similar types of evidence to establish independent development).

138. See supra note 90. 
injunction. ${ }^{139}$ At the same time, PI relief would remain available to patent owners who are harmed by defendants that copied their technology or engaged in other unethical conduct, because these defendants would be unable to establish independent invention. Further, this proposal is in accord with important patent policy goals of fostering and protecting innovative efforts, which are discussed more fully in the next Section.

\section{B. Policy Arguments for Limiting the Use of Preliminary Injunctions in Patent Infringement Lawsuits}

Several important patent policy arguments support the limited inclusion of an independent invention defense in the PI context. Discouraging deliberate infringement while promoting overall innovative efforts, deterring rent-seeking behavior in the form of predatory licensing, and increasing economic efficiency in patent incentives are discussed in this Section as policies that are consistent with the independent invention affirmative defense. First, patent law generally disfavors culpable and intentional patent infringement. ${ }^{140}$ This disfavor is manifested in the willful infringement context, where the punitive enhancement of infringement damages are rcserved for cases where patcnt rights are deliberately and flagrantly infringed. Similar concerns inform the factors courts consider in granting PIs, namely that the extraordinary remedy of PI relief be preserved for rare cases where the court finds unilateral action early in litigation to be equitable to prevent infringement of valid patent rights. Introducing independent invention as an absolute bar to PI relief is in accord with these policy concerns. It targets for PI relief those cases involving the most culpable conduct on the part of defendants. Additionally, it postpones remedies in cases where there is evidence that the defendant may have innocently infringed. Finally, it defers questions of whether

139. This benefit becomes especially important when the defendants are dealing with small PLFs, sinee lieensing fees comprise small PLFs' entire revenue stream. If a court later determined that a PI had been improperly granted, there is eonsiderable risk that the PLF could not remedy the damages since its assets may not be able to cover the patent owner's lost profits and other damages that may far exceed the comparatively smaller licensing fees. Federal Rule of Civil Proeedure 65 attempts to remedy this situation by requiring the Pl applieant to provide to the other party pre-Pl security for payment of costs and damages suffered in the event the adverse party is "found to have been wrongfully enjoined or restrained." FED. R. Clv. P. 65(c). Thus, if the PI is found to be incorrect, the plaintiff is liable to the defendant for any losses that the PI caused. Id. Nonetheless, courts have reserved the discretion to deny the defendant recovery on the bond if the plaintiff sued in good faith. See, e.g., H\&R Bloek, Inc. v. MeCaslin, 54I F.2d 1098, 1099-1 100 (5th Cir. 1976) (per curiam). Further, in the event of a long trial or large damages, the vindicated defendant still could suffer significant undercompensation by the PLF.

140. Trade secret law offers rich examples of which behaviors constitute culpable conduct and should be punished. PIs should target culpable conduct that ranges from direct copying of issued patent disclosures to conduct that would be considered misappropriation under trade secret law, including theft, breach of confidence, and industrial espionage. See infra notes 205-07 and accompanying text. Misappropriation of patented technology is analogous to trade secret misappropriation and unfair competition torts. 
independently invented innovation is infringing the patent owner's rights until the end of trial. An independent invention defense would spare firms that are able to make a strong showing of their commercial ethics from the risk of PIs, while leaving vulnerable those firms that are engaged in questionable behavior and that cannot mount a credible independent invention affirmative defense.

Without penalties, parties may have an incentive to copy or steal technologies disclosed in patents or in their corresponding commercial embodiments rather than undergoing the expense of independently developing the technology. In Saes Getters S.p.A. v. Ergenics, Inc., a district court issued a PI against a defendant partly based on the equitable consideration that the defendant had established a pattern of "deliberately set[ting] out to copy plaintiff's invention and incorporate minor deviations to avoid infringement." 141 In Minnesota Mining and Manufacturing Co. v. Johnson \& Johnson Orthopedics, the Federal Circuit upheld a Special Master's willfulness determination with its punitive enhancement of infringement damages, as appropriate based on defendant's unethical business conduct. ${ }^{142}$ Noting the intense business and technical rivalry between the firms, the court observed that the defendant had "wrongfully acquired and misappropriated" a new technology and its derivative products before the related patent issued, and further the defendant had a pattern of copying the innovations embodied in each of the patent owner's products in an effort to remain competitive. ${ }^{143}$ These cases accord with patent policies of protecting innovation by penalizing unethical commercial conduct, namely copying and misappropriation of patented technology, with stricter penalties. My proposal is in line with these important policy concerns, in that it continues the availability of PIs to restrain infringers engaged in unethical commercial conduct.

Second, on a related note, this proposal would deter intentional conduct while promoting overall, ethical innovation. Independent invention may occur quite commonly and innocently. ${ }^{144}$ Firms often are in a race to develop a new technology, and both or several may have filed patent applications on the same or similar technology. While prosecuting competing patents, different firms may have entered the marketplace with competing products. ${ }^{145}$ Even in situations where parties are not in an explicit race and are unaware of their competitors, they may independently develop

141. 816 F. Supp. 979, 987 (D.N.J. 1992).

142. 976 F.2d 1559, 1581-82 (Fed. Cir. 1992).

143. Id. at 1582 .

144. See infra note 187 and accompanying text.

145. Some patent infringement cases have been filed within days of a patent issuing. See, e.g., State Indus., Inc. v. A.O. Smith Corp., 751 F.2d 1226, 1236 (Fed. Cir. 1985) (recounting that the patent owner sued the defendant twenty-two days after its patent issued and without notifying the defendant of the alleged infringement). 
technologies that infringe a competitor's claim or happen to fall within the scope of a broad patent. In rare cases, submarine patents have issued and surprised a competitive market years later. ${ }^{146}$ There is a strong policy argument against issuing a PI in such a scenario. The patent system is designed to foster innovation, and innocent infringers invest in R \& D efforts to discover new technologies rather than piggyback off their competitor's discoveries. Under current PI standards, there is a danger that innocently infringing defendants that are engaged in legitimate independent $R$ \& D efforts could be denied, during trial while validity and infringement are being sorted out, access to technologies that they invested in developing. PI relief is especially inappropriate in a race scenario in which interference proceedings to determine first inventorship may be pending ${ }^{147}$ or further discovery may uncover evidence calling patent validity strongly into question.

Third, and most important in the PLF context, this proposal would deter predatory licensing practices by augmenting the accused defendant's defensive strategies to such infringement claims. By producing evidence of their own R \& D efforts, companies continually facing PLF letters charging them with infringement will be better able to resist such demands for licensing fees. As previously discussed, the growing trend toward accumulating diverse intellectual property portfolios of enforceable patents has manifested itself in several ways. The trend ranges from nonmanufacturing PLFs, which accumulate and enforce a hodgepodge of idle patents by collecting licensing fees from accused infringers, ${ }^{148}$ to manufacturing companies, many with strong $\mathrm{R} \& \mathrm{D}$ efforts and correspondingly powerful portfolios of overlapping patents in the same technological niche. ${ }^{149}$ As a general matter, withholding PI relief from the PLF in the first scenario is less controversial than withholding relief from the competing firms in the second scenario because competing firms are engaged in the innovative behaviors that the underlying patent policies are designed to encourage. Unfortunately, substantive rules governing PI relief must cover both situations. However, a rule of independent invention would curtail PLF

146. See Sandburg, Inventor's Lawyer, supra note 44. Sandburg noted:

[Jerome Lemelson's] patents were dubbed submarine patents because of their decades-long submergence in the PTO. Lemelson submitted his original application on machine vision in the 1950s. While the first patent on the technology issued in 1963, additional patents weren't granted until the 1980s when the technology was in widespread use.

Id. See also supra note 2 and accompanying text.

147. The U.S. patent system only awards patent protection to the first inventor. See 35 U.S.C. $\S 102(\mathrm{~g})(2000)$ (stating that a person shall be entitled to a patent unless another person previously developed the invention). It also provides procedures for determining the first inventor. MANUAL OF Patent Examining Procedure $\S \S 2300-2365$ (8th ed. 2001) (describing rules controlling interference proceedings in the PTO between two applicants involving patent elaims covering the same technology).

148. See supra notes $41-45$ and aceompanying text

149. See supra notes 51-58 and accompanying text. 
enforcement activities that allege infringement by the key technological innovations of target manufacturing corporations. If the target is able to establish independent invention, the PLF would be required to litigate its infringement claims to their conclusion before obtaining a court-ordered remedy. Since PLFs are often interested in easily-acquired royalty payments with minimum effort and expense, targets are more likely to bargain down the high royalty demands or litigate the patent with greater confidence that their business or key products would not be shut down.

From a policy standpoint, then, allowing an independent invention defense would cover a broad range of patent enforcement situations, from the activitics of nonmanufacturing PLFs to large innovative corporations. It would focus on the behavior of the dcfendant, which would be protected from the sudden threat of PI relief when it follows commercially acceptable patterns of innovative behavior, and it also would provide an incentive to innovate. The accused infringer engaged in favored innovative behaviors would have an equally powerful defense against infringement allegations propounded by a PLF or a large corporate competitor. Thus, although an independent invention defense sacrifices some certainty early in litigation, it provides increased promotion of innovation and incentives for fairer settlements.

Finally, my proposal is in harmony with other academic proposals arguing for increasing the economic efficiency of the overall patent system. Professors lan Ayres and Paul Klemperer have argued for greater uncertainty and delay in the patent system. They argue that these changes would induce a limited amount of infringement, which would reduce the social deadweight economic loss that results from the monopoly pricing of patented inventions. ${ }^{150}$ They hypothesize that the ex post enforcement of patent rights-achieved through a reduction or elimination of available PI relief and an increased focus on compensation through monetary damage awards—could be an effective method of implementing this policy. ${ }^{151}$ Julie Turner has argued for providing monetary damages awards to the exclusion of all others in the specific context of "nonmanufacturing patent owners" that do not pursue commercialization. ${ }^{152}$ Effectively, removing PI relief as a remedy for nonmanufacturing patent owners (and only awarding

150. See Ayres \& Klemperer, supra note 87 , at $986-88$.

151. See id. at 988 ("Appreciating the benefits of uncertainty argues against giving patent owners a presumptive right to Pls against infringement, and militates instead in favor of relatively stingy ex post measures of make-whole damages."). Ayres and Klemperer further noted:

[U]ncertain enforcement need not open a floodgate of infringement. Instead of taking an essentialist view that the "very nature" of property entails the right to exclude, we suggest that the nature of patents should entail offering sufficient rewards to stimulate innovation. Uncertain monetary damages--possibly combined with extended durations-are sufficient to achieve this end. 
damages equivalent to the disclosure value of their patents) would promote economic efficiency. ${ }^{153}$

More significantly, there is a growing movement among legal and economic scholars towards increasing economic efficiency of the patent system by introducing a generalized independent invention defense to patent law. ${ }^{154}$ In particular, Stephen Maurer and Suzanne Scotchmer argue that the threat of an independent invention defense will increase market efficiency and preserve innovation by curbing the patent owner's market power without threatening the patent owner's ability to cover its R \& D costs. ${ }^{155}$ Under this scheme, a patent owner will have an incentive to license at lower cost, in order to deter potential independent inventors. ${ }^{156}$ Additionally, they argue that a general independent invention defense will promote efficiency by reducing duplicative $R$ \& $D$ costs incurred during patent races. ${ }^{157}$ Because the independent invention defense will limit royalties to a rate close to the cost of $R \& D$, a smaller number of firms, or even a single firm, will opt to enter the $\mathrm{R} \& \mathrm{D}$ race to obtain patent protection, thus reducing duplication costs, but that sufficient incentives remain for the development of the innovation. ${ }^{158}$

Allowing indepcndent invention as an affirmative defense to PIs would postpone infringement analyses until after discovery and a trial on the merits. This result harmonizes with the broader proposal by Ayres and Klemperer because an independent invention defense would introduce delay or uncertainty into the patent system. ${ }^{159}$ Refusing PI relief would permit limited amounts of infringement, namely infringement of litigated patents, to continue during the course of trial. Under the Ayres and Klemperer model, this result would be advantageous because limited incursions on the patent owner's monopoly power would have appreciable social benefits

153. Id. This is because nonmanufacturing patent owners have weaker claims to lost profits on sales of infringing goods because only the infringer is in the marketplace and it would not be equitable to award damages when the nonmanufacturing patent owner was not in competition with the infringer. Because of this absence of direct competition in the same or closely related market, the patent owner would be entitled only to a reasonable royalty or licensing fee. See id. at 208 (arguing that "the nonmanufacturing patent owner's remedy would be limited to actual lost profits or a reasonable royalty").

154. Stephen M. Maurcr \& Suzanne Scotchmer, The Independent Invention Defence in Intellectual Property, 69 EсоNоміса 535, 536 (2002) (arguing that an independent invention defense is efficient in any industry where the cost of independent invention is not much less than the original inventor's cost); Liebovitz, supra note 136, at 2268 (skctching a proposal for a patent system that protects patent owners against "free-riding competitors, but not against competitors who independently develop the same technology").

155. Maurer \& Scotchmer, supra note 154 , at 535.

156. Id. Under this scheme, a patent owner cannot rationally charge a higher licensing fee than the cost of inventing the patented technology independently. Otherwise its competitors would merely invent independently and the patent owner would get nothing. See id.

157. Id. at 541,545 .

158. Id. at 540

159. See supra notes 150-51 and accompanying text. 
(namely lowering monopoly prices to competitive levels on patented products) with only a minimal negative impact on incentives to innovate. ${ }^{160}$

Moreover, my proposal encourages parties to come to more economically efficient and equitable settlement agreements, ${ }^{161}$ as parties may be induced to make more accurate assessments of the merits of their respective cases. The grant or denial of a PI early in litigation has a significant impact on the relative bargaining power of parties during settlement negotiations. Anecdotal evidence suggests that the threat of PIs is an important factor that accused infringers consider in their settlement calculus. ${ }^{162}$ Additionally, issuing a PI may undermine the ability of parties to come to reasonable settlement terms. Having a PI in hand confers on the patent owner an enormous grant of bargaining power and, rather than be shut down, alleged infringers likely are more willing to accept inefficient settlements. ${ }^{163}$ Additionally, large companies whose key product lines incorporate allegedly patented technologies may be in a better position to litigate the dispute or settle it on fairer terms with the threat of PI relief removed. ${ }^{164}$

Although forcing parties to defer the disposition of their competing rights until after a trial would reduce certainty by withholding early indications of the strength of parties' cases, it would conversely promote greater certainty in ultimately and more accurately resolving the merits of the disputes. In deciding PI motions, courts must act at a special hearing significantly in advance of trial, based on sketchy motion papers, affidavits, and

160. See Ayres \& Klemperer, supra note 87 , at $986,989-90$ (proposing a model suggesting that small decreases in the patent owner's monopoly price would have larger impacts on social welfare than the patent owner's profits and would be partially offset by added profits from increased sales).

161. See Maurer \& Scotchmer, supra note 154, at 535 (noting that when faced with the possibility of duplication, perhaps through an independent invention defense, patent owners will have significant incentives to license to potential competitors); see also supra note 156.

162. See supra notes 30-31 and accompanying text.

163. In contrast, some courts have viewed injunetions as facilitating settlement discussions. In granting a permanent injunction in Mahurkar Patent Litigation, the court mused that the

injunction creates a property right and leads to negotiations between the parties. A private outcome of these negotiations-whether they end in a license at a particular royalty or in the exclusion of an infringer from the market--is much preferable to a judicial guesstimate about what a royalty should be. The actual market beats judicial attempts to mimic the market every time, making injunctions the normal and preferred remedy.

In re Mahurkar Double Lumen Hemodialysis Catheter Patent Litigation, 83I F. Supp. 1354, 1397 (N.D. 11l. 1993). Courts could view Pls as effecting much the same result. This argument is less powerful in light of the fact that parties could also bargain from a no-injunction position. Under the Coasian theory, assuming low transaction costs, parties will reaeh the optimal result irrespective of the legal rule. See Ronald Coase, The Problem of Social Cost, 3 J.L. \& Econ. 1, 2-15 (1960).

164. Some courts seem to have little regard for how P1 decisions may bear on parties' litigation strategies. Obviously, courts should seek to implement the law and be less concerned with how their decisions affect parties' litigation strategies. At the same time, they should be vigilant in closing loopholes in the legal standard that may foster rent-seeking behavior and economically inefficient settlements. See generally Frank B. Cross, In Praise of Irrational Plaintiffs, 86 CoRNELL L. REv. 1, 3, 32 (2000) (arguing that legal decision-makers should take behavioral models into account by discouraging strategic settlement behaviors that promote inefficient, rent-seeking behavior by some litigants). 
rough evidence, and without seeing all of the evidence or frequently affording the alleged infringer an adequate opportunity to present a full defense. ${ }^{165}$ By contrast, after hearing the parties' arguments based on a full evidentiary record and undertaking a full analysis, the factfinder is in a better position to make an informed decision regarding validity and infringement. Thus, the risk of an erroneous decision is reduced through the benefit of a full proceeding. If infringement is found after trial, judges can issue, with greater certainty and confidence, permanent injunctions to guard against future infringement and award damages for prior infringement, including the infringement that occurred during trial. It is the rare case of prima facie validity and infringement where a PI could be issued with the confidence that supports relief granted after trial, and in the interest of minimizing the erroneous issuance of PI relief, PIs should be reserved for such cases.

Notions of equity and economic efficiency indicate that introducing independent invention as a defense to PI motions would be in harmony with overall patent policies. Similar policy concerns are at work in other intellectual property law contexts where independent invention is employed in varying ways. The next Section considers how independent invention operates in these other contexts and the tensions and benefits that may be implicated by my proposal.

\section{Analogies to Other Areas of Intellectual Property Law}

Patent law is unique among intellectual property fields in not recognizing independent invention as a general defense to nonwillful infringement. ${ }^{166}$ The successful integration of the independent invention concept into willful patent infringement, copyright infringement, and trade secret misappropriation scenarios serves as an informative starting point from which to advocate its inclusion in patent law in the PI context. This comparative approach of considering solutions in other areas of intellectual property law is not new to the Federal Circuit, which has consistently looked to standards adopted in other areas of intellectual property law and analogized between patent law and those other disciplines. In particular, the Federal Circuit has historically relied heavily on copyright and trademark principles in shaping its PI jurisprudence. ${ }^{167}$ The court recently reconfirmed this approach of "[r]easoning by analogy from decisions involving

165. See supra notcs 64-65 and accompanying text. In addition to the rush to trial, it also forces defcndants surprised by litigation to make rapid assessments of whether to settle the case or risk exposure to a PI.

166. See Maurer \& Scotchmer, supra note 154, at 535.

167. See, e.g., Roper Corp. v. Litton Sys., Inc., 757 F.2d 1266, 1271 (Fed. Cir. 1985) (noting the Smith International approach and examining standards for issuing Pls in trademark cases); Smith Int'l, Inc. v. Hughes Tool Co., 718 F.2d 1573, 1581 \& n.7 (Fed. Cir. 1983) (borrowing from copyright cases in adopting a rule that presumes immediate irreparable injury in patent law). 
other forms of intellectual property." 168 Drawing on this accepted methodology, this Section analyzes the intersection of independent invention and intellectual property law in three distinct areas: willful infringement in patent law, the independent creation defense to copyright infringement, and misappropriation in trade secret law. The use of independent invention in other areas of intellectual property law provides a persuasive basis for implementing a limited version of the defense in patent law in the PI context.

\section{Independent Invention as a Defense to Willful Infringement in Patent Law}

Patent infringement is a strict liability offense that does not require a showing of intent. ${ }^{169}$ Nonetheless, notions of intent strongly shape the legal questions and policies underlying willful patent infringement. Willful infringement in patent law permits the imposition of an enhanced damage penalty of up to three times the actual damages for intentional infringement. ${ }^{170}$ Although the applicable statute allows these enhanced damages at the discretion of the trial court, ${ }^{171}$ the Federal Circuit interprets the statute as requiring clear and convincing evidence of the "willfulness" mens rea as a prerequisite for assessing enhanced damages. ${ }^{172}$ Courts evaluate willfulness under a totality of the circumstances approach ${ }^{173}$ by considering a series of factors, notably whether the defendant deliberately copiei the patent owner's designs, the defendant's motivation for harm, and the defendant's attempts to conceal its misconduct. ${ }^{174}$

168. High Tech Med. Instrumentation, Inc. v. New Image Indus., Inc., 49 F.3d 1551, 1556 (Fed. Cir. 1995) ("Reasoning by analogy from decisions involving other forms of intellectual property, this court has held that a presumption of irreparable harm arises when a patent owner makes a clear showing that a patent is valid and it is infringed.").

169. Hilton Davis Chem. Co. v. Warner-Jenkinson Co., 62 F.3d 15/3, 1520 (Fed. Cir. 1995) ("[l]ntent is not an element of infringement, independent development does not excuse infringement of the patent owner's right to exclude."); Roger D. Blair \& Thomas F. Cotter, Rethinking Patent Damages, 10 TEX. INTELL. PROP. L.J. I, 59 (2001).

170. See Ira V. Heffan, Willful Patent Infringement, 7 FED. CIR. B.J. 115, 116-17 (1997). Willfulness and treble damages derive from the Patent Act of 1793, I Stat. 318 (1793); see also SRI Int'l, Inc. v. Advanced Tech. Labs., Inc., 127 F.3d 1462, 1468 (Fed. Cir. 1997) (discussing the statutory history of enhanced patent damages).

171. 35 U.S.C. $\S 284(2000)$.

172. See Heffan, supra note 170 , at 119 (discussing the mens rea requirement); id. at 137 (discussing the clear and convincing evidence standard).

173. Underwater Devices Inc. v. Morrison-Knudsen Co., 717 F.2d 1380, 1390 (Fed. Cir. 1983) (formulating the totality of the circumstances test).

174. The nine factors a court must consider stem from two Federal Circuit decisions. Under Bott $v$. Four Star Corp., 807 F.2d 1567, 1572 (Fed. Cir. 1986), the eourt considered three factors in enhancing damages: (1) whether the defendant deliberately copied the ideas or designs of another; (2) whether the defendant, when he knew of another's patent, investigated the scope of the patent claim and determined a good-faith belief that it was invalid or not infringed; and (3) the defendant's behavior as a party to the litigation. Additional factors were enumerated by the Federal Circuit in Read Corp. $v$. Portec, Inc., 970 F.2d 816, 827 (Fed. Cir. 1992), namely: (4) the defendant's size and financial condition; (5) the closeness of the case; (6) the duration of the defendant's misconduct; (7) the 
Evidence of independent invention or good-faith attempts to design around patented technologies can rebut a finding of willful infringement. ${ }^{175}$ The indulgence of independent invention and good-faith attempts to design around patented technology stems from important policy goals underlying willful infringement: the punitive nature of enhanced damages are reserved for punishing instances of culpable infringement, such as misappropriation of patented technology. ${ }^{176}$ By contrast, R \& D expenditures to potentially develop patented technology and good-faith attempts to design around patents are innovative practices that patent law encourages. ${ }^{177}$ Thus, although failed attempts to design around patented technology and independent invention, which may occur when a party discovers a previously patented technology, may still trigger infringement liability, these attempts will not trigger enhanced willful infringement damages. ${ }^{178}$

defendant's remedial action; (8) the defendant's motivation for harm; and (9) whether the defendant attempted to coneeal its misconduct.

175. Good-faith attempts to design around patented technologies represent a middle ground between independent invention and direct copying. Such attempts presuppose access to the patented technology (for example, where the infringer had access to the patent or patented products in an effort to design a product or technology that escapes the literal claim scope). However, unlike willful infringement, good-faith attempts to design around patented technologies are not protectcd under my proposal because I have defincd independent invention as presupposing no actual access to the patented technology. See supra note 133; see also infra notes 226-29.

176. See Rite-Hite Corp. v. Kelley Co., 819 F.2d I120, 1126 (Fed. Cir. 1987) ("The role of a finding of "willfulness" in the law of infringement is partly as a deterrent-an economic deterrent to the tort of infringement-and partly as a basis for making economically whole one who has been wronged."); Powers \& Carlson, supra note 33, at 69-70. Powers and Carlson noted that

it remained the general rule until 1983 that a plaintiff could not obtain an award of increased damages unless it proved by clear and convincing evidence that the defendant consciously and willfully copied the patented invention. Courts justified imposing treble damages as a means to punish the misappropriation of patented tcchnology.

Id.; see also Heffan, supra note 170, at 117 (discussing the deterrence and punishment rationales for willful infringement).

177. Donald S. Chisum et al., Principles of Patent Law 62 (1998) (describing patent law policies fostering incentives to invent, disclose, commercialize, and design around patented technologies). See also WMS Gaming, Ine. v. Int'I Game Tech., I84 F.3d 1339, 1355 (Fed. Cir. 1999) ("When the district court reconsiders its finding of willful infringement, it should bear in mind that the patent law encourages competitors to design or invest around existing patents.").

178. State Indus., Inc. v. A.O. Smith Corp., 75l F.2d 1226, 1235-36 (Fed. Cir. 1985). The court found that

kecping track of a competitor's products and designing new and possibly better or cheaper functional equivalents is the stuff of which competition is made and is supposed to benefit the consumer. One of the benefits of a patent system is its so-called "negative incentive" to "design around" a competitor's products, even when they are patented, thus bringing a steady flow of innovations to the marketplace. It should not be discouraged by punitive damage awards except in eases where conduct is so obnoxious as clearly to call for them.

Id. See also Hilton Davis Chem. Co. v. Warner-Jenkinson Co. 62 F.3d 1512, 1523 (Fed. Cir. 1995) ("[U]nder the trial court's instructions, Warner-Jenkinson's evidenee of independent development played its proper role: it shielded Warner-Jenkinson from an enhanced damages award [for willful infringement], but did not provide a basis for avoiding application of the doctrine [of equivalents in infringement analysis]."). 
Despite doctrinal differences between willful infringement and general infringement analysis, notably the importance of subjective mental states and the heavy reliance of opinion letters in the willful infringement context, ${ }^{179}$ willfulness cases highlight important difficulties that arise in drawing lines between favored and disfavored innovative behaviors. The Federal Circuit has varied in its attempts at drawing a line. For example, at one end of the spectrum, in SRI International, Inc. v. Advanced Tech Laboratories, Inc., the court recognized independent invention as a partial defense to willfulness. It based its finding of willfulness on the "totality of the eircumstances" and determined that "independent invention or attempts to design around and avoid the patent or any other factors tending to show good faith" may be considered as exculpatory factors averting a finding of willful infringement. ${ }^{180}$ And on the other end of the spectrum, in Read Corporation v. Portec, Inc., the court discouraged copying of patented commercial products. ${ }^{181}$ It noted that the patent owner's ideas and designs, as embodied in commercial products and not just the patent claims themselves, should be considered in evaluating the infringer's direct-copying claims. ${ }^{182}$ The court disapprovingly acknowledged that the defendant used plaintiff patent owner's device as a "starting point" for its design efforts with a purpose of creating a competing device. ${ }^{183}$

179. Opinion letters from patent counsel have become virtual requirements in defending allegations of willful infringement. Due to the Federal Circuit's reliance on an objective standard of determining willfulness, the opinion letter requirement has come to dominate the willfulness analysis. See Lester L. Hewitt \& E. Randall Smith, The Effect of Ten Years of Federal Circuit Law on: Willful Infringement and Increased Damages, 35 IDEA 37, 41 (1994) (describing how the Federal Cireuit uses both a subjective standard and an objective approach, whereby "willfulness may be based on a finding that the party should have known it was infringing or relying on incompetent legal advice"); see id. at 46 ("By far, under both pre and post-Federal Circuit law, the most important single piece of evidence is the opinion of counsel."). In Underwater Devices Inc. v. Morrison-Knudsen Co., 717 F.2d 1380, 1390 (Fcd. Cir. 1983), the Federal Circuit imposed an affirmative duty on potential infringers. The court required potential infringers, before condueting any potentially infringing activity, to determine whether or not they were infringing by seeking competent legal advice from counsel. This required parties to seek legal opinion letters to assess the validity of the patent claims and to ascertain whether the parties' behavior had infringed the claims.

180. 127 F.3d 1462, 1465 (Fed. Cir. 1997).

181. 970 F.2d 816 (Fed. Cir. 1992).

182. Id. at $827 \& \mathrm{n} .7$ (finding that in determining "whether the infringer deliberately copied the ideas or design of another," the "'[i]deas' and 'design' would encompass, for example, copying the commercial embodiment, not merely the elements of a patent claim.").

183. The court nonetheless found no willful infringement on other grounds. $1 d$. at 828 . Specifically, the Federal Circuit overturned the finding of willfulness based on Portee's procurement of "two independent written detailed opinions of unrclated patent counsel" advising them how to make specific changes to the product to avoid infringement. Id. at 829 . Similar results have occurred in other cases where courts have balanced opinion letters and evidence of direct copying and found no infringement. See, e.g., Westvaco Corp. v. Int'l Paper Co., 991 F.2d 735, 740, 743 (Fed. Cir. 1993) (overturning a district court's finding of willful infringement and enhanced damages based on the conclusion that Westvaco relied on "good faith on timely and competent opinions from its patent counsel" despite the district court's finding that "Westvaco engaged in deliberate and obvious attempts to copy sueccssful IP products" after they wcre patented); In re Mahurkar Double Lumen Hemodialysis 
The defendant's behavior at the time of the issuance of a patent also has come under scrutiny in willful infringement analysis. The Federal Circuit has been hesitant to find willful infringement by a party already practicing an invention immediately after a patent has issued. ${ }^{184}$ Commenting on willfulness in such a situation, the court noted that "[w]hether an act is 'willful' is by definition a question of the actor's intent, the answer to which must be inferred from all the circumstances. Hence a party cannot be found to have 'willfully' infringed a patent of which the party had no knowledge." 185 Because patent applications were kept secret until issuance, ${ }^{186}$ absent evidence of misappropriation or consent of the patent owner, a party practicing an invention at the time the patent issued must have independently invented the technology. This doctrine reflects the reality that often multiple inventors produce patented technologies at roughly the same time. ${ }^{187}$ In such cases, inventors may be unaware that others have created or are in the process of developing and patenting the technology at issue. Where even a diligent search of issued patents would not reveal anything to put them on notice, these inventors may have no way of knowing that they may be infringing.

Catheter Patent Litigation, 831 F. Supp. 1354, 1395-96 (N.D. Ill. 1993) (noting that willful infringement was "strongly suggest[ed]" by the faet that one infringer had "knocked-off" the product it had purchased from another infringer which was originally derived from the patent owner's product, but refused to find willful infringement because of the presence of four legal opinion letters).

184. Gustafson, Inc. v. Intersystems Indus. Prods., Inc., 897 F.2d 508, 510-1l (Fed. Cir. 1990). But in some cases, copying a produet before issuance of the related patent is treated as strong evidence of willful infringement. See, e.g., Kaufman Co. v. Lantech, Inc., 807 F.2d 970, 979 (Fed. Cir. 1986); Milgo Elec. Corp. v. United Bus. Comm., Inc., 623 F.2d 645, 666 (10th Cir. 1980).

185. Gustafson, 897 F.2d at 510-1I.

186. Recently, the Patent Act was amended pursuant to the General Agreement on Tariffs and Trade, Trade Related Aspects of Intellectual Property ("GATT TRIPs") agreement to provide for publication of patent applications eighteen months after filing for patent owners that plan to pursue patent protection in other countries. See 35 U.S.C. \& I22(b) (2000). However, this assumption in Gustafson that patents are secret until issued is still relevant for parties practicing inventions at the time patent applications are published.

187. Robert P. Merges \& Richard R. Nelson, On the Complex Economics of Patent Scope, 90 Colum. L. Rev. 839, 884 (1990) (discussing patent races); see also Philippe Signore, On the Role of Juries in Patent Litigation (Part II), 83 J. Pat. \& Trademark Off. Soc'y 896, 926 (200I) ("The patent laws recognize the possibility of nearly simultaneous invention by two or more equally talented inventors working independently, and provide that the fact of near simultaneous invention does not in and of itself preclude, or rule out, patentability."). See, e.g., Spitting Image, ECONOMIST, Sept. 21, 2002, at $2 \mathrm{I}$, for an example of this simultaneous patenting phenomenon:

The thermal inkjet printer was invented not once, but twice. The idea was conceived simultaneously, and unbeknown to one another, by two competing teams on either side of the Pacific. In Japan, Ichiro Endo, an engineer at Canon, noticed ink squirting from the neck of a syringe when a hot soldering iron touched it. Thousands of miles away at Hewlett-Packard's laboratories in Silicon Valley, a researcher called John Vaught dreamed up his version of the thermal inkjet by borrowing from the mechanism of the coffee percolator.... Two years later, Hewlett-Packard found out about Canon's work. The patents for many of the key inventions in both research efforts had been filed within months of one another. 
Willful infringement jurisprudence, then, tends to favor independent invention and good-faith attempts to design around patented technologies, while discouraging direct copying and misappropriation. These notions are justified as encouraging behaviors that tend to produce innovation, while discouraging free-riding or rent-seeking behaviors and have close analogs to the independent invention defense proposal. Courts, including the Federal Circuit, have made a policy judgment that innovative behaviors, even if unsuccessful in a particular instance, should be encouraged because they tend to increase the level of overall innovation. If a firm actively engages in its own R \& D project and happens to lose the race to patenting because other firms are likewise employed in similar efforts, ${ }^{188}$ punitive damages should not be assessed for interim infringement resulting from the use of technology that the infringing firm also developed.

Further, willful infringement also implicates notions of equity and fairness in its imposition of remedies. Withholding enhanced damages for rare cases of culpable infringement has a synergy with denying the extraordinary remedy of a PI except in situations where the defendant is clearly infringing and cannot affirmatively show that the alleged infringement, if it occurred, was innocent. ${ }^{189}$ Thus, the policy argument underlying both willful infringement and my proposal is that remedies should not prohibit and punish socially useful behaviors. Since patent law explicitly encourages innovation and the dissemination of technological developments, Pl relief should not deter legitimate efforts to develop new technologies that would be characterized as independent invention in subsequent litigation.

\section{The Independent Creation Defense to Copyright Infringement}

Likewise, copyright law heavily implicates notions of independent innovation. Much like patent law's policy goal of fostering of technological innovation, copyright law aims to encourage the production and dissemination of creative works. But it differs from patent law by favoring varying levels of creative duplication and overlap over exclusive rights. ${ }^{190}$

188. See Maurer \& Scotchmer, supra note 154, at 540-42 (same); Merges \& Nelson, supra note 187 , at 884 (discussing patenting races).

189. A difficult case is presented by cases where the plaintiffs can make a crcdible showing of irreparable harm, but the defendant meets its burdcn of establishing independent invention. Under this proposal, if the defendant can meet its burden of independent invention, the plaintiff is denied P1 relief. This outcome may seem superficially unfair. However, my proposal presupposes that innocent innovative efforts should be privileged at the expense of PI relief, and notes that if infringement is found at the conclusion of a full trial, the plaintiff will be remedied with damages and a permanent injunction.

190. Robert P. Merges et al., Intellectual Property in the New Technological Age 350-51 (2d ed. 2000) (discussing copyright law's policies of promoting artistic creation); id. at 354-55 (noting the mere requirement of de minimis originality to create a new work); id. at 433-34 
In copyright law, independent creation is both a requirement for copyright protection and a defense against claims of infringement. In Feist Publications, Inc. v. Rural Telephone Service Company, Inc., the Supreme Court held that, to be eligible for copyright protection, a work must be original, or in other words, independently created. ${ }^{191}$ Courts subsequently have interpreted Feist to mean that an author is entitled to copyright protection for any independently created work, even if that work lacks novelty and is identical to a prior work. ${ }^{192}$

To establish copyright infringement, a plaintiff must show that it owns the copyright to the work and that the defendant copied the work. ${ }^{193}$ Copying may be established by direct or indirect evidence. ${ }^{194}$ As a practical matter, it is rarely possible to establish copying by direct evidence. ${ }^{195}$ More commonly, copying can be established by indirect evidence that

(highlighting the difficulty in determining copying among two works because many works draw on elements in the public domain).

191. 499 U.S. 340,345 (1991). The Court held:

To qualify for copyright protection, a work must be original to the author. Original, as the term is used in copyright, mcans only that the work was independently created by the author (as opposed to copied from other works), and that it possesses at least some minimal degree of creativity.

Id. (eitation omitted).

192. Boisson v. Banian Ltd., 273 F.3d 262, 270 (2d Cir. 2001). See also Acuff-Rose Music, Inc. v. Jostens, Inc., I55 F.3d 140, I43 (2d Cir. 1998) ("Originality does not signify novelty; a work may be original even though it closely resembles other works so long as the similarity is fortuitous, not the result of copying.") (quoting Feist, 499 U.S. at 345). But see Selle v. Gibb, 74I F.2d 896, 901 (7th Cir. 1984) ("However, beeause direct evidence of copying is rarely available, the plaintiff can rely upon circumstantial evidence to prove [copying], and the most important component of this sort of circumstantial evidence is proof of access."). Judge Learned Hand provided a hypothetical example of an identical, noninfringing work in his famous quote in Sheldon v. Metro-Goldwyn Pictures Corp., 81 F.2d 49, 54 (2d Cir. 1936):

Borrowed the work must indeed not be, for a plagiarist is not himself pro tanto an 'author'; but if by some magic a man who had ncver known it were to compose anew Keats's Ode on a Grecian Um, he would be an "author," and, if he copyrighted it, others might not copy that poem, though they might of course copy Keats's.

Id.

193. See Feist, 499 U.S. at 361 ("To establish infringement, two elements must be proven: (1) ownership of a valid copyright, and (2) copying of constituent elements of the work that are original.").

194. Arnstein v. Porter, 154 F.2d 464, 469 (2d Cir. 1946) ("As to the first-copying-the evidence may consist (a) of defendant's admission that hc copied or (b) of circumstantial evidenceusually evidence of access-from which the trier of the facts may reasonably infer copying.").

195. See Susan Wakeen Doll Co. v. Ashton-Drake Galleries, 272 F.3d 441, 450 (7th Cir. 2001) ("[D]irect evidence of copying is normally unavailable."); Roth Greeting Cards v. United Card Co., 429 F.2d I 106, 1110 (9th Cir. 1970) (same). For examples of where direct evidence of copying existed, see Rogers v. Koons, 960 F.2d 301, 307 (2d Cir. 1992):

[T]his case presents the rare scenario where there is direct cvidence of copying. Koons admittedly gave a copy of the photograph to the Italian artisans with the explicit instruction that the work be copied. Moreover, the importance of copying the very details of the photograph that embodied plaintiff's original contribution-the poses, the shading, the expressions - was stressed by Koons throughout the creation of the sculpture.

Id; Narell v. Frccman, 872 F.2d 907, 910 (9th Cir. 1989) (noting that the defendant "admitted consulting [the plaintiff's] book during her research and taking 'language' from it”). 
demonstrates that the defendant had access to the copyrighted work and the two works are substantially similar. ${ }^{196}$ Many courts have held that once a plaintiff has established access and substantial similarity, the burden shifts to the defendant to introduce evidence of independent creation. ${ }^{197}$ Thus, independent creation in copyright law also functions similarly to an affirmative defense, in shifting the burden to the defendant to establish that it did not copy, and thus did not infringe.

Blair and Cotter have proposed two practical reasons to explain the disparate treatment of independent invention in copyright and patent law. First, the independent creation of noninfringing but identical, or nearly identical, copies of existing copyrighted works is rarc and thus defendants rarely invoke independent invention as an affirmative defense in copyright law. ${ }^{198}$ This infrequent occurrence stands in stark contrast to patent law, where overlapping or substantially identical claimed inventions frequently are developed, often almost contemporaneously. ${ }^{199}$ Second, because conferring upon copyright owners the ability to enjoin independently created, substantially similar works would have a chilling effect on speech, the ratio of protected works to unprotected works is higher in copyright than in patent law. ${ }^{200}$ These differences in the patent and copyright law regimes help to explain the different treatments of independent invention between them. Because patent law provides comparatively stronger protection for innovative ideas, while copyright law merely protects expression rather than the underlying ideas, these fundamental differences explain why the contours of independent invention in the regimes may be qualitatively different. However, copyright law can nonetheless provide valuable insights on how independent invention should be implemented in patent law.

196. See, e.g., Joy Mfg. Co. v. CGM Valve \& Gauge Co., 730 F. Supp. 1387, 1399 (S.D. Tex. 1989) (noting that "copying" for purposes of a copyright infringement claim is established by showing that the accused infringer had access and substantial similarity existed between the accused and copyrighted works). In some cases, if there is a "striking similarity" between accused and copyrighted works, courts may infer copying without proof of access. See Susan Wakeen Doll Co., 272 F.3d at 450 ("Thus, if the works rescmble each other so closely as to make it highly unlikely that the challenged work was 'an accident of independent creation,' then the similarity 'is evidence of aceess."). Note that even if a work is copied, the copying may not be actionable. In Feist, the defendant infringer admitted to copying the plaintiff's telephone listings, but the court refused to impose liability because the copied eleinents were not themselves original, noting that "[n]ot all copying . . . is copyright infringement." Feist, 499 U.S. at 361. See also Melville Nimmer \& David Nimmer, Nimmer on Copyright $\S 13.01[B]$, at 13-9-13-10 (2002).

197. See, e.g., Original Appalachian Artworks, Inc. v. Toy Loft, Inc., 684 F.2d 821,829 (11th Cir. 1982) ("[P]roof of access and substantial similarity raises only a presumption of copying which may be rebutted by the defendant with evidence of independent creation."); Kamar Int'l., Inc. v. Russ Berrie \& Co., 657 F.2d 1059, 1062 (9th Cir. 1981) (noting that once the copyright holder demonstrates access and substantial similarity to her work, the burden shifts to the accused infringer to prove that the work was independently created).

198. See Blair \& Cotter, supra note 169 , at 59 n.268.

199. Id. See also supra note 187 and accompanying text.

200. Blair \& Cotter, supra note 169 , at 59 n.268 
In particular, copyright law may inform how the independent invention proposal should address the difficult issues of intentional "design-arounds" of patented technologies, which frequently occur in patent law. Copyright law takes an interesting approach to the difficult issue presented by the defense of intentional dissimilarity - where the defendant intentionally tries to make his work dissimilar from a prior copyrighted work. In the easy case where the overall language of the two works is the same but some words are merely substituted or inverted, courts have held that such crude efforts are themselves evidence of copying. ${ }^{201}$ By contrast, when the defendant bases his work in part on a prior copyrighted work but makes broad, significant changes to the work overall, this should not be infringement. ${ }^{202}$ Intentional dissimilarity in copyright law has a strong relation to attempts to design around technologies in patent law since both doctrines address questions of infringement when protected works are used as the starting point for future creative or technical innovation. The prior copyright hypotheticals indicate that different degrees of the same behaviors may implicate different outcomes: small, superficial substitutions are held to infringe while major modifications to existing works are encouraged. Similar arguments could be made for design-arounds in the patent regime: holding blatant copying with small changes in nonessential details as infringement while arguing that broader changes, perhaps using different design means to arrive at the same ultimate functionality, should be encouraged as innovative behavior.

The intermediate cases are perplexing, and infringement should arguably be decided on a case-by-case basis. Since my proposal relates only to independent invention in the rarer context of PI relief, not a generalized independent invention defense to infringement, it is possible and necessary to avoid such shaded inquiries because of the burden imposed on defendants that propound this affirmative defense. ${ }^{203}$ Under the proposed clear evidence standard, ${ }^{204}$ it is unlikely that subtle attempts at designing around a patented product would qualify as independent invention under my proposal because they are almost indistinguishable from copying. However, for cases of dramatic changes, defendants retain the argument that their product is in effect a new species falling outside the scope of plaintiff's patent claims and perhaps deserving of independent patent protection.

201. See, e.g., Atari, lnc. v. N. Am. Philips Consumer Elecs. Corp., 672 F.2d 607, 619 (7th Cir. 1982) (noting that the defendant employer's directions that an employee make "certain superficial changes" to the competing work "may be viewed as an attempt to disguise an intentional appropriation of [protectable] expression").

202. NimMER \& NimMER, supra note 196, § 13.03[B][1][b] at 13-56 to 13-57 (arguing that a scenario in which a defendant has intentionally made broad changes to a work should not bc infringement).

203. See infra notes 223-24 and accompanying text.

204. See supra note 136 and accompanying text. 
Thus, defendants may be able to make a credible argument that they do not infringe in the first instance, rather than putting forth the defense that it does not matter that they infringe because they independently invented.

\section{Independent Invention in Trade Secret Law}

Trade secret law imposes liability for trade secrets. Under trade secret laws, independent invention is an absolute defense to misappropriation charges. The Uniform Trade Secret Act ("UTSA") defines "misappropriation," in part, as an "acquisition of a trade secret . . . by a person who knows or has reason to know that the trade secret was acquired by improper means...."205 "Improper means" includes theft, bribery, misrepresentation, breach of a duty to maintain secrecy, or espionage. ${ }^{206}$ Trade secret misappropriation is frequently based on tortious or criminal conduct, breach of a confidential relationship, or eavesdropping. Recent formulations in the UTSA and the Restatement of Torts find that improper means need not be illegal or criminal but must "fall below generally accepted standards of commercial morality and reasonable conduct." 207 Importantly, however, trade secret law also recognizes several lawful means for acquiring trade secrets, including independent invention, accidental disclosure, and reverse engineering. ${ }^{208}$ Thus, analogies to trade secret misappropriation can provide valuable insights into acceptable and unacceptable innovative practices. In the patent context, a plaintiff's ability to present evidence that defendant misappropriated its technology would strongly undermine a defendant's claim to independent invention. A court should question the efficacy and legitimacy of a defendant's independent $R$ $\&$ D efforts if a plaintiff can establish that the defendant's employees stole or engaged in industrial espionage in order to acquire knowledge of the plaintiff's technology.

By contrast, the Restatement of Unfair Competition, the UTSA, and cases interpreting them conclude that independent invention is a legal means of obtaining trade secrets, and thus a complete defense to claims alleging trade secret misappropriation. ${ }^{209}$ Accordingly, multiple parties may

205. UNif. Trade Secrets Act $§ 1(2)$ (i) (1985). Further, disclosure or use of a trade secrct also constitutes misappropriation if the accused knew that another person obtained the trade secret through improper means or through a breach of a duty to maintain secrecy. See id. $\S 1(2)$.

206. Id. §1(1).

207. Restatement of Torts $\S 757 \mathrm{cmt}$. f (1939); see Unif. Trade Secrets Act $\S 1 \mathrm{cmt}$. (1985); E.l. duPont deNemours \& Co. v. Christopher, 431 F.2d 1012 (5th Cir. 1970) (holding that taking photographs during legal aerial reconnaissance of the plaintiff's partially constructed plant constituted improper means for obtaining information).

208. See Unif. Trade Secrets ACt $\$ 1 \mathrm{cmt}$. (1985).

209. See id; Restatement (ThiRd) of Unfair Competition $\S 43$ (1995) ("Independent discovery and analysis of publicly available products or information arc not improper means of acquisition"); see also Kewanee Oil Co. v. Bicron Corp., 416 U.S. 470, 476 (1974). The Court held:

A trade secret law, however, does not offer protection against discovery by fair and honest means, such as by independent invention, accidental disclosurc, or by so-called reverse 
be the legal owners of the same trade secret. ${ }^{210}$ This principle's tension with patent law's premium on conferring exclusive rights has been recognized by both courts and commentators. ${ }^{211}$ The Supreme Court has contrasted the limited scope of trade secret protection against that afforded by patent law, where independent discovery of a patented invention is prohibited:

Trade secret law provides far weaker protection in many respects than the patent law. While trade secret law does not forbid the discovery of the trade secret by fair and honest means, e.g., independent creation or reverse engineering, patent law operates "against the world," forbidding any use of the invention for whatever purpose for a significant length of time. ${ }^{212}$

Thus, the Supreme Court justified the absence of a generalized independent invention defense in patent law by the fact that the defense would undercut the exclusivity that the patent system confers. ${ }^{213}$ The patent system grants such exclusivity because of the full public disclosure patent owners give their innovations. Although this well-established bargain might argue against introducing a generalized independent invention defense in patent law, the concern does not present a compelling argument in the narrow ease of averting PI relief in patent law based on clear evidence of

engineering, that is by starting with the known product and working backward to divine the process which aided in its development or manufacture.

Id.; Chicago Lock Co. v. Fanberg, 676 F.2d 400, 405 (9th Cir. 1982) ("A lock purchaser's own reverseengineering of his own lock, and subsequent publication of the serial number-key code correlation, is an example of the independent invention ... expressly allowed by trade secret doctrine."); Christopher, 431 F.2d at 1015 ("[O]ne may use a competitor's process if he discovers it by his own independent research; but one may not avoid these labors by taking the process from the discoverer without his permission at a time when he is taking reasonable precautions to maintain its secrecy.'); Miller v. Owens-11linois, 1nc., 187 U.S.P.Q. 47, 48 (D. Md. 1975) (holding that a prior, independent discovery was a complete defense to liability for trade secret misappropriation).

210. See Surgidev Corp. v. Eye Tech., Inc., 648 F. Supp. 661, 688 (D. Minn. 1986) (recognizing that "several developers of the same information may have trade rights in that information"); see also RESTATEMENT (THIRD) OF UNFAIR COMPETITION $\S 40 \mathrm{cmt}$. f (1995) ("Independent discovery by another who maintains the secrecy of the information, for example, will not preclude relief against an appropriation by a third person.").

211. See, e.g., Andrew Rodau, Prior Restraints and Intelleetual Property: The Clash Between Intellectual Property and the First Amendment from an Economic Perspective, 12 FoRDHAM 1NTELL. Prop. Media \& ENT. L.J. 1, 61-62 (2001). Rodau noted:

But reliance on trade secret law runs the continuing risk of a third party developing the process via independent invention or reverse engineering. Learning the process by either method allows the third party to freely use the process as its own. Additionally, disclosure of the process to the industry destroys the existence of the trade secret and any eorresponding economic advantage it provides. In contrast, independent invention and reverse engineering do not affect the rights of a patent owner.

Id. (footnotes omitted).

212. Kewanee Oil, 416 U.S. at 489-90.

213. Trade secret law confers weaker protection but parties keep their innovations secret from their competitors. By contrast, in patent law, as part of the exchange for full technical disclosure, the patent owner is awarded the strong protection of exclusivity. 
independent invention. In the context of my proposal, an independent invention affirmative defense does not permanently erode a patent owner's exclusive rights and deny it of a remedy altogether, but merely suspends exclusivity for a brief time and delays the question of remedies until after a trial on the merits.

Although independent invention has been employed to varying degrees in copyright and trade secret law, and within the context of patent law in willful infringement determinations, implementing the defense against PI injunctions in patent law is not without potential problems. The next Section considers concerns that may need to be addressed in adopting my proposal.

\section{Implementation and Problems}

Although my proposal would lessen opportunities for abuse of PIs by patent owners and further the patent system's important policy goals (especially the promotion of innovation), it would not automatically eliminate all of the problems and ambiguities that plague current Pl standards. The proposal presents some additional issues that must be addressed.

First, evidentiary problems may arise when the defendant independently invented the technology at issue but lacks the evidence to demonstrate it in court. ${ }^{214}$ Thus, if the plaintiff-patent owner makes a strong showing under the traditional factors, the defendant may be unable to rebut it with the independent invention defense and in all likelihood a PI would issue due to lack of adequate proof. These problems of proof, however, will likely resolve themselves if the independent invention defense is

214. For example, the defendant may not be able to prove that it developed the invention in a clean room without access to patented products or technologies. The software industry currently requires the defendant to prove this development procedure. Additionally, the defendant may not be able to prove that it notarized lab notebooks or otherwise independently documented and verified its inventive process.

Many companies, notably software companies, have already adopted "clean room" development methods to foreclose claims of copyright infringement by direct copying of a competitor's product by isolating their employees in an environment with limited development materials. Sega Enters., Ltd. v. Accolade, Inc., 977 F.2d 1510, 1526 (9th Cir. 1993) ("A 'clean room' is a procedure used in the computer industry in order to prevent direct copying of a competitor's code during the development of a competing product. Programmers in clean rooms are provided only with the functional specifications for the desired program."). Many courts have recognized an independent crcation defense for similar software independently developed in clean room environments. See, e.g., NEC Corp. v. Intel Corp., 10 U.S.P.Q.2d (BNA) 1177, 1188 (N.D. Cal. 1989) (noting that "it is reasonable to conclude that the same constraints, rather than copying, were responsible for the principal similarities between [microcode developed in a clean room] and the Intel microcode"). The entertainment industry undertakes similar precautions, often returning unsolicited scripts unopened. See Dimmie v. Carey, 88 F. Supp. 2d 142, I 48 (S.D.N.Y. 2000) (noting the defendant songwriter's "statements that it was against their [corporate] policy and practice to review unsolicited tapes"). 
adopted, as companies would adjust to the new legal standard and implement appropriate procedures to protect themselves. ${ }^{215}$

A second problem this proposal encounters is how courts should treat the defendant's actual or constructive notice of the patent owner's technology. Blair and Cotter's study, which endorses independent invention as a means to improve economic efficiency in the context of patent damages, is instructive on this matter. As part of their study, they examined whether it was efficient to award patent damages in situations in which the accused infringer independently invented the patented invention. ${ }^{216}$ They focused specifically on the provisions of 35 U.S.C. $\$ 287$, which precludes infringement damages unless the patent owner provided actual or constructive notice (via product marking) to the infringer ${ }^{217}$ Although they did not conclusively resolve the question of whether to require the accused infringer to have actual notice or knowledge of the patent as a prerequisite to awarding patent damages, Blair and Cotter suspected that this is the preferred solution. ${ }^{218}$ They offered several reasons for their hypothesis, including the substantial search costs that firms incur from searching issued and pending patents to determine if their technology or products infringe and the lower burden on the patent owner to provide actual or constructive notice. ${ }^{219}$ By giving actual or constructive notice of patent protection, then, the patent owner could avoid the harm of infringement at a lower cost than the potential infringer ${ }^{220}$ Further, it may seem unfair to award damages to a nonmanufacturing patent owner if the infringer is not aware of the infringement. ${ }^{221}$

Similarly, this rationale specifically applies to the remedy of PI relief by allowing independent invention to be argued as an affirmative defense when issues of notice are involved. Certainly, evidence that the defendant had actual knowledge of the patent owner's technology would undercut any claim to independent invention. ${ }^{222}$ Where notice was constructive or

215. This responsiveness of sophisticated companies to new legal rules was demonstrated in the willful infringement context. After the Federal Circuit strongly suggested a legal opinion letter would be necessary to discharge an alleged willful infringer's affirmative duty to ensure it was not infringing after receiving notice of a patent, obtaining such letters became common practice. See Powers \& Carlson, supra note 33, at 108 (arguing for the abandonment of the legal rules which "essentially compel alleged infringers to obtain opinion letters and then proffer them at trial").

216. Blair \& Cotter, supra note 169 , at 59-60.

217. Id. at 64 .

218. Id. at 65 .

219. Id. at $65-66$.

220. Id. at 66.

221. See id. (questioning whether nonmanufacturing patent owners should be permitted to recover lost profits on sales of goods that compete with the infringing product if the infringer is unaware of the patent).

222. Obviously, if the defendant were admittedly aware of the precise nature of the patent owner's technology, thus betraying some level of access to plaintiff's technology, disproving allegations of copying would be almost impossible. 
absent, however, the issue becomes more complicated. In some cases, a lack of actual notice should not preclude good-faith claims to independent invention. For example, it would not constitute sufficient notice for a defendant to have a rough idea that a research team at another eompany or university was working on solutions to the same or closely related problem. In this situation, the defendant would have only vague details or suspicions regarding implementation and would not have benefited sufficiently from its suspicions, except perhaps to expedite its own R \& D efforts. In fields with high levels of collaboration (and especially in academia), unawareness of what others were working on would be virtually impossible and a standard that pcnalizes such knowledge could lead to the undesirable result of discouraging collaboration.

Issues of eonstructive notice are complex, and may depend on timing. Claims of independent invention are likely most credible when the independent invention resulted from a patent race or has occurred within a short span of the first discoverer. Thus, claims of independent invention while the invention was still confidential should provide a stronger evidentiary basis, while claims of independent invention that occurred aftcr the issuance of a relevant patent or the publication of a patent application are significantly less crcdible. However, allowing this type of constructive notice to undercut claims of independent invention would provide a stronger incentive for inventors to file a patent application and immediately publish their inventions or send notices to their direct competitors. Independent inventors could avoid this problem by following clean-room development techniques, which have been relied on in other industries. Constructive notice is a coneern courts should evaluate on a ease-by-case basis.

Third, this proposal encounters significant line-drawing concerns in trying to differentiate between prohibited and encouraged behaviors. In general, policies promoting innovation generally favor independent invention and good-faith design-arounds, while discouraging direct copying and misappropriation of another's ideas and innovations. These same linedrawing problems are encountered in willful patent infringement, copyright infringement, and trade secret misappropriation. ${ }^{223}$ But categorizing conduct can be quite complex: how should a court distinguish between behavior one party argues is direct copying while the other eontends is a failed good-faith endeavor to design around a patented invention? ${ }^{224}$ This ambiguity is only magnified at the PI stage, where evidence may be spotty and circumstantial at best.

223. See supra notes 189, 201-04, 207-08 and accompanying text.

224. See Powers \& Carlson, supra note 33, at 96 ("There is a fine line between designing around a patent, and copying patented technology."). 
The evidentiary concerns are remedied by the clear and convincing evidence standard required under this proposal. ${ }^{225}$ This standard places the burden squarely on defendants to establish their independent invention, rather than exploit plaintiff's circumstantial or ambiguous evidence of copying, thus alleviating this problem. The problem of how to distinguish copying from attempts to design around a patented invention is alleviated by the definition of independent invention and strongly informed by the prior discussion of actual notice. ${ }^{226}$ Under my proposal, by definition, independent invention presumes that the accused infringer had no actual access to the patented technology. Thus, actual access, which is required to allege good-faith attempts to design around existing innovations, is not protected as independent invention. Although design-arounds are innovative activities that patent law promotes, allowing them to qualify as a variety of independent invention under my proposal would present undesirably complex, intensely factual issues at the PI stage early in litigation. ${ }^{227}$ Due to this danger of evidentiary ambiguities, namely disputes over whether the technology was being copied (and thus not independently invented) or instead merely studied and modified, there is a substantial chance that courts may make decisions that will later prove erroneous. Although my proposal is not incompatible with good-faith design-around efforts, it would not provide a safe harbor for such activities at the PI stage, and would instead defer that decision until the conclusion of a full trial.

Finally, as an alternative, and more conservative, approach to my proposal, independent invention could be considered as a separate, fifth, factor in the PI inquiry or merely as a consideration under an existing factor, such as the irreparable injury or likelihood of success factor. ${ }^{228}$ Thus independent invention would be onc factor to be weighed in the analysis, and may be determinative in close cases. For example, instead of independent invention functioning as an absolute bar to a PI as under my proposal, evidence of independent invention could be considered as an equitable factor tending to undermine the grant of a PI. Thus, if a patent owner presents a reasonable case of a likelihood of success on the merits that fails to provide a presumption of irreparable harm, independent invention could rebut the patent owner's arguments regarding actual irreparable harm and weigh against issuance of the PI. This approach is similar to the willful infringement

225. See supra note 136 and accompanying text.

226. See supra notes 201-02 and accompanying text.

227. See supra note 165 and accompanying text.

228. The irreparable harm requirement ensures that $\mathrm{Pl}$ relief is designed to penalize and deter egregious conduct that has caused harm to the patent owncr. For example, if another company copies its patented technology or misappropriates its ideas while patent applications are pending, the patent owner is harmed by the free riding resulting from the copying or misappropriation. Without making an independent investment in developing the technology, the other firm has taken the patent owner's ideas at low or no cost, and perhaps has been benefited by a head start in commercializing or improving the technology than if it had to independently develop its own solution. 
inquiry in the patent context, where evidence of copying is merely one factor to be weighed in the totality of the circumstances analysis. ${ }^{229}$

As discussed, my proposal implicates practical concerns regarding lack of evidence and notice. Further, line-drawing difficulties exclude the innovative behavior of good-faith design-around activities from the definition of independent invention under my proposal. However, adding a defense at the PI stage is an important first step in protecting innovative behaviors by shielding innovative firms from aggressive enforcement tactics early in litigation.

\section{CONCLUSION}

The increasingly aggressive character of patent enforcement prompt a reevaluation and potential revision of patent legal standards in order to close the legal loopholes that foster such rent-seeking behavior. In particular, PIs are an important strategic consideration and area of potential uncertainty of firms contemplating licensing demands. This has only been complicated by ambiguities in the PI legal standard that have led to confusion among the lower courts and have contributed to the Federal Circuit's continual revision and clarification of the PI standard. The experiences of independent invention in other areas of intellectual property law can intelligently inform and highlight concerns that must be addressed in adapting it as a defense to PI motions in patent infringement lawsuits.

Introducing independent invention as an affirmative defense into this narrow area of patent law will serve several beneficial purposes. It will benefit firms engaged in ethical innovative efforts by removing one of the key weapons patent enforcers hold over their target company-the threat of shutting them down. In light of aggressive patent enforcement practices PLFs may be deterred from asserting patents that will not survive validity challenges and infringement defenses during trial or may agree to lower royalty payments. Under my proposal, with proof of independent invention, remedies will only be potentially assessed after trial. It will delay but not deprive patent owners of a remedy for actual infringement during trial; patent owners will still be entitled to damage awards for infringement before and during trial, and permanent injunctive relief to bar future infringement after trial. Further, PI relief is preserved for rare cases where the defendant copied or misappropriated the patent owner's technology, and thus cannot mount a credible defense of independent invention. Although denying patent owners PI relief during trial might abridge their rights somewhat and introduce uncertainty in the early stages of trial, such erosions will arguably promote overall social welfare and economic efficiency while largely preserving the patent owner's incentives to innovate. 